\title{
Manifestations of Institutional Reform and Resistance to Reform in Ulster Workhouses, Ireland, 1838-1855
}

\author{
Liz Thomas ${ }^{1}$
}

Published online: 1 April 2017

(C) The Author(s) 2017. This article is published with open access at Springerlink.com

\begin{abstract}
The new Irish and English poor laws of the nineteenth century were based on ideologies prevalent during the period of Improvement. The workhouse was the central instrument of these new Acts. Through an archival and archaeological methodology, this paper investigates the physical manifestations of the governing ideologies of reform and improvement and the manifestations of resistance to this reform in one type of institution, Ulster's nineteenth-century workhouses (a province that spans Northern Ireland and the Republic of Ireland). It also reflects on how these once despised institutions are now used, through community efforts, as recreational and "reform" centers.
\end{abstract}

Keywords Workhouses $\cdot$ Ideologies $\cdot$ Reform $\cdot$ Ireland

\section{Introduction}

The Ideology of Improvement had impacted on "all spheres" of society, including implementing modern agricultural techniques, industrial advancement, landscape design and civic Improvement (through the construction of model villages and new rural housing) and ultimately, the reformation of the poor by the late eighteenth and early nineteenth century (Tarlow 2007). At this time in England and Ireland, Improvement "meant both profit and moral benefit" (Tarlow 2007: 13). In 1838, the Poor Law Act ("An Act for the more effectual relief of the destitute poor in Ireland," 1 \& 2 Vic., c. 56) was passed and proved to have the most conservative measures of any poor law act in England, Wales, and Scotland because ultimately, in Ireland poverty relief was only allowed when the recipient resided within the workhouse. The policy of the Workhouse

Liz Thomas

1.thomas@qub.ac.uk

1 School of Natural and Built Environment, Queen's University Belfast, Belfast BT7 1NN, Northern Ireland 
Test (only residents of the workhouse could receive relief) embraced the "test of less eligibility" (conditions within the workhouse, where residents received relief, were inferior to the conditions obtained through labour by the lowest class of worker). The policies of the nineteenth - century poor laws enacted in Ireland (1838) and Britain (1834) were based on the ideologies of Adam Smith, Jeremy Bentham, and Thomas Malthus, who were undoubtedly influenced by the ideology of Improvement. The main objective of the 1838 Poor Law Act (Ireland) was to remove pauperism and simultaneously relieve destitution and improve the "Irish character" through the introduction of a universal workhouse system: The workhouses built in Ireland under this new act were specifically designed as a visual reminder to reform both those resident and not resident in the workhouses.

"The very sight of a well-built efficient establishment would give confidence to the Board of Guardians; the sight and weekly assemblage of all servants of their Union would make them proud of their office: the appointment of a chaplain would give dignity to the whole arrangement, while the pauper would feel it utterly impossible to contend against it" (Head in Jackman 1958: 63).

By 1842 Ireland was divided into 130 Poor Law Unions, and a workhouse was to be built central to each of these. The Unions were to be based as in England, on a market town, "equally distributed over the country," equal in size and with a ten-mile radius. The Poor Law Commissioners (Commissioners) favored larger Unions as they believed that these were more economical and they tried to observe the preexisting local boundaries, so as to make the Unions as "compact and complete as possible" (Fifth Annual Poor Law Report 1839: 23-25). Forty-three of these Unions were created in the province of Ulster. By 1846 the 130 workhouses, one for each Union, were erected, just in time to meet the Great Famine. However, the impact of the Great Famine made the Commissioners resolve that further Unions and workhouses were required due to severe overcrowding and mortality. Between 1847 and 1855 a further 33 new Unions and workhouses were established across Ireland. Only one of these second-phase workhouses, the Bawnboy Union, was constructed in Ulster.

There has been extensive research on the Poor Law Act in Ireland, ranging from broad historical and economical accounts (Crowley et al. 2012; Gray 2009; Purdue 2011) to local historical studies on several workhouses across Ireland and Britain (Crawford 2004; Crossman 2003; Lucas 1999; O’Mahony 2008; Scannell 2006). Historical archaeologists have established that institutional buildings reflect ideologies, and identified the ritual and symbolic use of space (De Cunzo 1995, 2001; Lucas 1999; McKee 1992; Piddock 2001, 2007). Various studies have used archaeological and historical resources to uncover a landscape of power relations and power dynamics that existed across and within institutions (Baugher 2001, 2010; Casella 2000, 2001; Spencer-Wood 2010). This paper will address, using archaeological and archival methods, how ideologies of reform could not be entirely transmitted through the building structures of the Irish workhouses and also how those objects of reform, the workhouse inmates, positively impacted on the buildings of reform.

\section{Ideologies and Reform}

Britain has an extensive history of poor law legislation dating as far back as the fourteenth century. Most of the laws passed between 1310 (in the reign of Edward II) 
and 1597 (at the initiation of an older Poor Law in England) dealt with vagrants and beggars. Traditionally, the dissolution of the monasteries in the sixteenth century, the conversion from arable to pasture farming, the economic crisis of the mid-fourteenth century, the Black Death and concern for social control impelled the passing of several acts to deal with poverty relief (Fraser 2003: 33; Slack 1999: 5). It was argued that the Black Death changed relief of the poor from being a personal Christian duty to a primary government mission (Fraser 2003: 33). From the 1530s, poverty started to be seen as a communal rather than an individual problem (Fraser 2003: 34). By 1601, with the passing of the Elizabethan poor law, the British government recognized that poverty was not merely a result of idleness but also a consequence of external environmental and social factors. The Elizabethan poor law, originally passed in 1597 and amended in 1601, was a consolidation of earlier poor laws and also offered clarity in the legislation and administration of the relief of the poor within the parishes (Daunton 1995: 447; Fraser 2003: 35). However, over time opposition to this law (the Old Poor Law) started to mount, especially by the end of the eighteenth century when costs of relief were steadily rising along with poverty. Three major concerns - cost, administration, and effects of public relief on society - drove the government to believe that central organization and control of relief was fundamental, hence following a Royal enquiry, there followed the implementation of the Amended Poor Act in England (or the New Poor Act in England) in 1834 (Trevelyan 1973: 351).

The Irish legislative history of poor relief was not as extensive as that in England. This history was partly because of the continued practice of the Brehon Laws up to the arrival of Cromwell and which finally ceased after the plantation of Ireland. Under Cumhal Senorba a portion of the "tribe land was set apart for the maintenance of the childless and indigent members of the clan" (Costello 1913: 426-27). However, throughout the eighteenth and nineteenth centuries several acts were introduced to deal with large-scale poverty, famines and disease prevalent at that time in Ireland. There was, however, a general distinction made in the earlier Irish acts between the deserving and undeserving poor, those who were unable to support themselves through labor and those who chose not to labor. A small number, approximately nine, of poorhouses, alms houses and houses of industry were established as a result of legislative measures in the eighteenth century. This is a very small number compared to the 3765 workhouses in England and Wales by 1801 (Daunton 1995: 454). Hence, after the Act of Union in 1800 between Britain and Ireland, the British government turned to Ireland and sought solutions for the extant poverty there.

The new Workhouse System in Ireland was exceptional for several reasons. Firstly, it was a colossal undertaking; secondly, the new poor law in Ireland was a radical attempt to manipulate and mold people - to change the people's morality and habits, to reconstruct the land and maybe even to create an invisible population of "innocuous and useful" laborers who served the needs of the wealthy through institutionalization (Bernard 1805: 10); and thirdly, it seems that this was the first time in the history of Irish and British poverty legislation that governing ideologies were intentionally manifested physically as well as legislatively. George Nicholls, a Poor Law Commissioner who played a major part in the formulation of the new poor law in Ireland, admitted that the workhouse was central to the successful implementation of the new legislation: 
It is important to bear in mind, however, that the workhouse constitutes the basis of the whole measure about to be established, and that as on the efficiency of the workhouse all will depend, so are the Commissioners, by the $35^{\text {th }}$ section of the Act, made responsible for providing a competent building in size and arrangement, and so fitted up and furnished as they "shall deem most proper for carrying the Act into execution (Fifth Annual Report of the Poor Law Commissioners 1839: 28).

The Commissioners who drafted the poor laws for England and Ireland adopted the main ideologies of Adam Smith (1723-90), Jeremy Bentham (1748-1832), and Thomas Robert Malthus (1766-1834), and created key policies which were driven by their ideologies of laissez-faire, centralization, classification, discipline and the Workhouse Test. Bentham, Malthus, and Smith considered the topics of laissez-faire (the government's non-interference in the free-economic market), education, poverty relief and the reasons for poverty (Bentham 2001a [1796], 2001c [1797]; Malthus 1807; Smith 1805). Ironically, the same influential ideologues were not completely united on the subject of poverty relief. Bentham, an Utopian visionary, and Malthus, a pragmatic and opposed to Utopian ideas, had contrasting ideas on the treatment of the poor, while the ideologies of Smith and Bentham conflicted on the issue of centralization. The government adopted the main principles of Smith, Bentham, Malthus with the implementation of the Workhouse Test. Smith's idea on laissez-faire was taken almost verbatim by the government. In economic terms, laissez-faire means non-governmental interference. Laissez-faire was one of the main policies of the new legislation that limited out-relief in England (1834) and stopped out-relief in Ireland (1838) because the government believed that industrial capitalism would provide the necessary employment to maintain the poor (Skuse and Jones-Owens 1983: 7-8). Their ideologies were reflected somewhat in the workhouses in England and Wales. However, it was in the workhouses built in Ireland that their ideologies were ultimately manifested (Thomas 2013).

However, it is clear that the legislators picked key aspects of their ideologies, and ignored others, with some contradictions, to suit their agenda of implementing the Workhouse Test in Ireland. The Workhouse Test demanded that applicants for poverty relief had to demonstrate their need was genuine by taking up residence within the workhouse; no relief would be offered those who refused workhouse residence. In England out-door relief, the provision of food and clothes to those who were not resident in the workhouse, was permitted. Within the workhouse the test of less eligibility was applied through the implementation of segregation by gender, age, and condition, onerous work for the able-bodied, frugal diet, enforcement of cleanliness, order, and ventilation. Regulation of all aspects of life was marked by bell ringing, the wearing of a workhouse uniform, and not being allowed leave the workhouse premises without permission. Nicholls stated that the governing principle of the workhouse was "that the support which is afforded at the public charge in the workhouse, shall be, on the whole, less desirable than the support to be obtained by independent exertion" (Nicholls 1837, p. 23). It was believed that the Workhouse Test and the test of less eligibility would restore the natural social order by deterring those seeking relief and inviting only the utterly desperate into the workhouse. Nicholls commented on the loss of freedom, "Confinement of any kind is more irksome to an Irishman than it is even to an Englishman [...he will] never enter the workhouse, unless driven thither for refuge 
by actual necessity; and he will not then remain there one moment longer than that necessity exists" (Nicholls 1837: 14).

George Nicholls (1837: 6) echoed Bentham's sentiments on poverty, Malthus' feelings on morality, and the enduring policy of less eligibility:

Now poverty is not the cause, or at least not the sole and immediate cause, of this mode of living of the Irish peasantry.... This may partly be attributed to the remains of old habits....A part also must be owing to a want of education, and of self-respect; and a part likewise to their poverty....to which last cause alone, every thing that is wrong in Ireland is invariably attributed (Nicholls 1837: 6).

In fact, Nicholls believed that what he perceived as the recklessness of the Irish resulted in overpopulation, depression, alcoholism, begging, and poverty. He observed that "Mendicancy and wretchedness have become too common to be disgraceful":

During my progress through the country, it was impossible not to notice the depression of feeling, morally and personally, of the Irish peasantry, and this to an extent which a stranger could not witness without very painful emotions... They seem to feel no pride, no emulation; to be heedless of the present, and reckless of the future. They do not (speaking of the peasantry as a whole) strive to improve their appearance, or add to their comforts (Nicholls 1837: 5, 6).

He said that laziness primarily contributed to the Irish condition and that they (the Irish) "will not exert themselves for work but are keen to attend markets, weddings, fights, horse races and funerals; wherever there is whiskey." Nicholls described Irish men as holding no respect for wages or time because their work can be "done any day." He disapproved that the heaviest burden of work fell upon the women and that they did not save for the future. He commented that the Irish peasants, in their "desultory and idle habits" endeavored " "to pull through' as they call it, with the smallest amount of means, they are very apt to under-calculate the extent of their wants, and often squander their store so early, as to be left without food before the new crop is ripe" (Nicholls 1837: 6-9). Finally, after Nicholls had finished battering the Irish character, he recommended the Workhouse Test in Ireland, assuring his readers that this system would "morally and socially" reform the entire population (Nicholls 1837: 9).

The Workhouse System was the government's "Invisible Hand." It formed part of the natural order that did not forcibly interfere with poverty relief, and therefore adhering to the principle of laissez-faire, but in a civilized society did not allow people to starve to death. The workhouse was the government's tool of social reform, representing the principles of uniformity, less eligibility, economy, and the abolition of out-door relief. It was believed that the new Irish workhouses had the physical capability to enforce the principal policies of the new Poor Law Act (Ireland).

\section{Workhouse Buildings}

Towards the end of the 1830 s, the Commissioners realized that the newly constructed and converted workhouses throughout England and Wales did not satisfy the 
stipulations of the new Poor Law (1834), uniformity and economy, because of the diverse building types. Between 1834 and 1839, over 350 new workhouses were constructed in England (O'Dwyer 1997: 13) and old parish workhouses were modified to suit the criteria of the new Union workhouse (Morrison 1999: 53). Hence, workhouses with a diversity of architectural plans and styles were the legacy of over 500 years of English poor law reform (Morrison 1999: 53). The Commissioners held that the variety of workhouses in England and Wales was not indicative of the principal policy of the new law, namely, the centralization of poverty relief. One opponent to the Poor Law described it as "watching an elaborately devised machine fail to start" (Walter in Crowther 1981: 30). The new workhouse was intended to be a powerful symbol of the new approach to poverty relief and reform. It was the necessary "machinery" that would "ensure a successful result in the struggle about to commence against pauperism" (Poor Law Commission 1836: 23). Commissioners recommended the "mixed workhouse" (Poor Law Commission 1836: 23) that would accommodate all classes of paupers (infants, children, able-bodied adults, the elderly, and ill and all categories of people were segregated by gender) under the one roof. This system, it was believed, was more efficient than the previous workhouses with financial, moral, and administrative advantages being derived (Poor Law Commission 1836: 23-25). This approach was reported successful in England, where men had been "emancipated from pauperism" (Poor Law Commission 1836: 25).

The Commission attempted to regulate the construction of workhouses in England and Wales by publishing plans of model workhouses. These designs were largely influenced by Bentham's Panopticon, with emphasis on Bentham's ideas of natural ventilation and observation, though observation into all areas of the buildings was limited (First Annual Report of the Poor Law Commissioners, 1835; Morrison 1999: 46). The implementation of these plans did not escape criticism. In some cases, they were condemned as being prison-like in form (which is not surprising because Bentham had prisons and all other forms of institutions in mind when he designed the Panopticon), whilst others were reproved for appearing like "paupers' palaces" (Digby 1986: 12).

With this experience in England, the Commissioners approached the Irish workhouse with a fervent desire for uniformity. Initially, Nicholls believed that buildings, such as poor-houses, barracks, and factories could be converted into Union workhouses. However, he did recognize that using a converted building would have a "material influence" on creating the center of the Union (Fifth Annual Report of the Poor Law Commissioners 1839: 36). The new Poor Law Act (Ireland 1838) stipulated that the workhouse was to be at the center of the Union (see above). Nicholls abandoned the idea of converting buildings (except in three Unions outside Ulster Dublin, Clonmel, and Fermoy). As with everything related to the new legislation introduced to Ireland, including the creation of Unions and the election of Guardians, the workhouse buildings were all executed with "regularity, order and economy" (Fifth Annual Report of the Poor Law Commissioners 1839: 36). The new act could really only be implemented when the workhouses were completed. The legislation directed that only the Commissioners were to be responsible for the workhouse design (Fifth Annual Report of the Poor Law Commissioners 1839: 31). This stipulation was purposefully included because it meant that the Commissioners, especially the eager Nicholls, had absolute control over the workhouses to be built in Ireland and enabled 
the erection of the building that would contain all the principles and ideologies of reform driving the new Act.

\section{Wilkinson's Appointment}

The Commissioners tenaciously executed their policies of poverty relief. This execution is especially apparent in the arrangements for the workhouse-building contract. Consultant architects in Ireland did not compete for workhouse contracts as they did in England. Instead, three architects were invited to Ireland to submit their plans (Gould 2003: 9). It would appear that at this point the Commissioners had already chosen their architect, Mr. George Wilkinson. As far as the Commissioners were concerned, his workhouse designs were "on the whole the most successful, and [gave] the greatest satisfaction, as regards arrangement and economy" (Fifth Annual Report of the Poor Law Commissioners 1839: 33). The Commissioners in Dublin had given Wilkinson instructions to design "a series of plans of different capacities, capable of holding from 330 to 1,300 inmates" (Fifth Annual Report of the Poor Law Commissioners 1839: 33). The Commissioners chose Wilkinson because he had already erected workhouses in Wales, which they believed was a similar environment to Ireland, and also because his buildings cost (at least in theory) considerably less than the buildings in England (Gould 2003: 9). Wilkinson's plans were revised at least twice before they were accepted by the Commissioners, who declared "we consider them, both in respect of economy and arrangement, preferable to any of the other plans devised for Irish workhouses which have come under our notice" (Fifth Annual Report of the Poor Law Commissioners 1839: 33-34).

In Ireland, a total of 130 workhouses were erected between 1838 and 1843 . For the first time in Irish and British history, workhouses were built with a distinct architectural identity, expressing the idea of classification and the principle of uniformity. Wilkinson's specifications for the construction of all of these workhouses were unyielding. In fact, every single detail was planned, even down to the location of the builder's temporary hut during the construction of the workhouse and the type, shape, and weight of the nails to be used. He was suitably pedantic as an employee of the Poor Law Commission. Outdoor relief was totally forbidden and this aspect of the legislation would have accounted for the comparatively large size of the workhouses in Ireland. Despite the extra size, Wilkinson initially achieved savings of one third of the cost of the buildings constructed in England, a principal policy of the Poor Law. Expenditure was reduced by a lower standard of accommodation in comparison to English workhouses. For example, his plans called for earthen floors instead of timber, and were considered suitable especially for the Irish inmates because, "both in point of economy and in being better adapted to the habits of the people, most of whom will be without shoes and stockings, and have been accustomed to floors of common earth in their cabins" (Seventh Annual Poor Law Report 1841: 204). Wilkinson also introduced his own cost-saving innovations: sleeping platforms instead of bedsteads in the dormitories. Wilkinson's sleeping platforms (Sixth Annual Poor Law Report 1840); whitewashing instead of plastered internal walls; and bare rafters instead of ceilings (Sixth Annual Poor Law Report 1840).

Ventilation was a major part of Wilkinson's new plans. Besides disease being particularly terrifying to the Victorians, cleanliness was directly linked to moral order 
(Fitts 2001: 123-128). It was widely held that Ireland was "in crying need" of cleanliness, neatness, and comfort" (Whately 1836: 7). Part of the Guardians' role was to appoint a visiting committee, which would examine the "cleanliness and ventilation of the workhouse." The "orderly behaviour" thus achieved was directly linked with the cleanliness of both the building and the inmates (Sixth Annual Report of the Poor Law Commissioners 1840: 136).

Wilkinson further developed the workhouse model plan with the innovative introduction of ventilation towers and turrets. As Foucault (1977:146) appreciated, the maintenance of central surveillance, segregation, and ventilation was a challenge. Wilkinson's towers and turrets, together with the open stairs, met these challenges and also made a formidable architectural impression. Where introduced, these towers made the building look taller but more especially, gave the impression of a watch tower. Although not designed as places of observation, the towers gave the impression of "the gaze" (Foucault 1977) that looked beyond the workhouse on to the surrounding town. It was envisioned that the workhouse would also be an instrument in the reform process of those outside the building because of the workhouses' austere and dominating presence on the landscape.

\section{The Plan}

Wilkinson designed two plans, which differed only in size (Figs. 1 and 2). Both plans consisted of three main parts: the front building (entrance and Guardians' rooms); the main building (able-bodied adults and children); and the infirmary buildings (to accommodate the sick and mentally ill). After 1848, Wilkinson arranged these same set of buildings in a different layout to accommodate changes in how children were perceived (Thomas 2013). By 1848, the perception of children's morality, even those children in the workhouses, had changed such that they were perceived as superior to adults. Thus easier to reform, children were housed at the front of the new workhouse with a vista to life and hope beyond the workhouse (Thomas 2013). Nevertheless, the same principles of uniformity and classification applied. The only workhouses in Ulster not built to the standard plan were those in Ballycastle, Dunfanaghy, and Castlederg, possibly because of the small population, meaning less funds, of these unions. Any irregularities or non-conformities were banished from the workhouse standard plan.

\section{Ideologies of Reform Reflected in the Irish Workhouse Plan}

\section{Centralization}

In 1838, when the Act was passed, there was absolutely no doubt that the Commissioners were to be responsible for the entire process of its execution in Ireland. George Nicholls, possibly the most ardent commissioner, drafted the new act and his input guaranteed that his ideas would be executed and offered him total control over the poor relief system in Ireland. The Commissioners seemed convinced that the new legislation, with the workhouse as its pivotal instrument, was really for the benefit and reform of the Irish people. For example, when dealing with Irish people they recommended "caution and forbearance, as well as firmness" (Fifth Annual Report of 


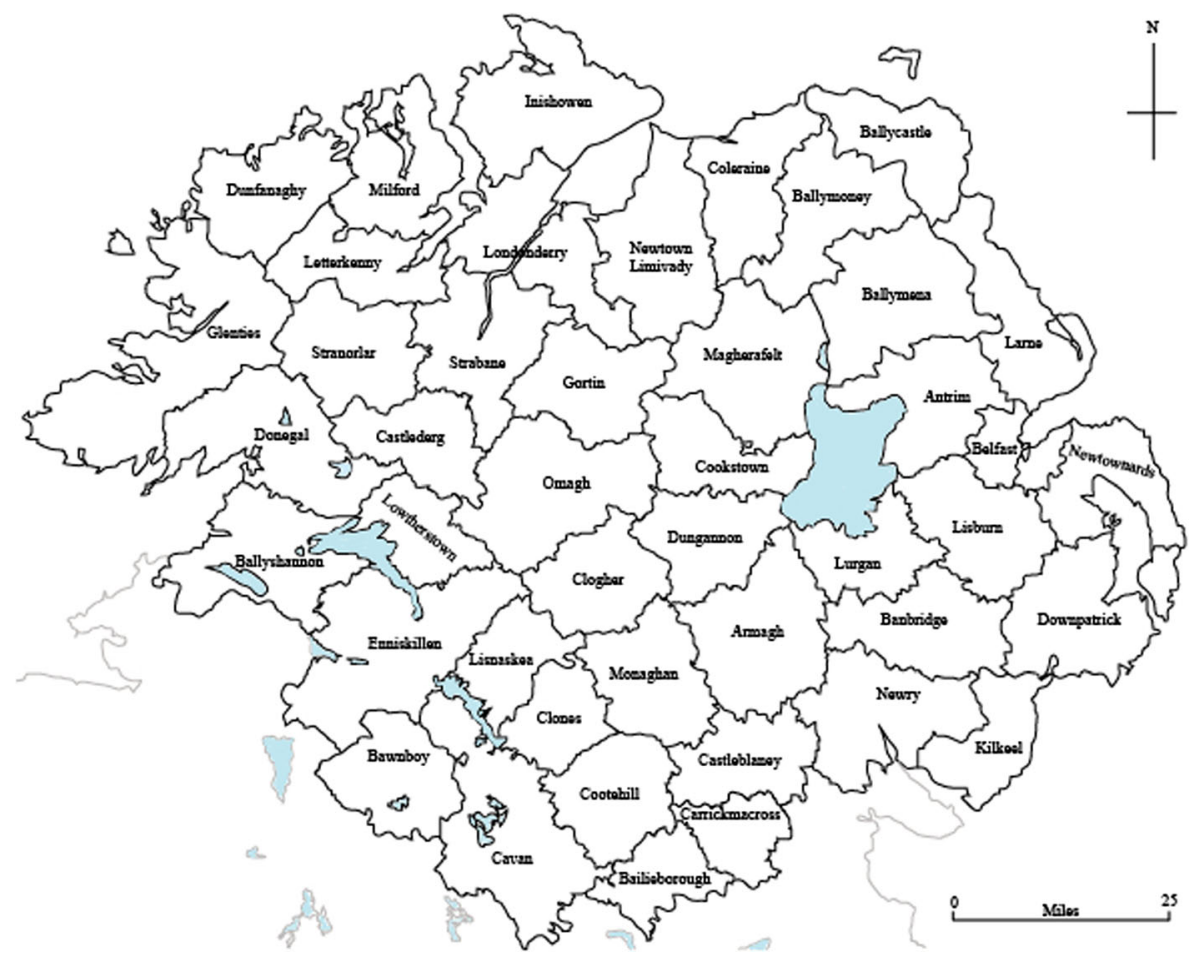

Fig. 1 Ulster map showing Unions. Area of study

the Poor Law Commissioners 1839: 27). In fact, they were so confident in the new law that they considered it "kind and beneficent, and calculated to better the condition and improve the social habits of the people" (Fifth Annual Report of the Poor Law Commissioners 1839: 28). Their goal was to establish an entirely unified network of institutions following "one rule, one system, in detail as well as in principle throughout the whole country" (Nicholls in Fifth Annual Report of the Poor Law Commissioners 1839: 28). The commission expected that their work in Ireland, unlike in England, would be "orderly and harmonious" (Nicholls in Fifth Annual Report Of The Poor Law Commissioners 1839, p. 28). Hence, legislation ensured that the Commissioners were entirely responsible for the establishment of the workhouses, preferably with the concurrence and co-operation of the Guardians, who in this great operation were also part of the reform process.

Jeremy Bentham's key philosophy incorporated into the new Poor Law was centralization, effectively institutionalizing poverty relief (Beales 1953: 16). Following his insistence on centralized inspection, the Poor Law Commission, comprised of Commissioners and their assistants, was established. The process of centralization involved the election of a Board of Guardians for each union. Though the Guardians directed the purchasing of the workhouse site, construction, and the management of the inmates, they did not make the ultimate decision on any of these issues. The final authority was vested in the Commissioners. Similarly, the master of the workhouse exercised absolute control within each individual workhouse. The positioning of the master's room was deliberately central, serving both functional and symbolic ends. His 
room overlooked every section of the workhouse, in theory at least. Like the government, he too continuously observed those under his watchful eye. Symbolically, he represented the centrality of disciplinary order (Foucault 1977: 167-68).

The desire for uniformity was possibly motivated by a fear of social disintegration and a need to maintain discipline. Some paupers in parts of England rioted on the implementation of the new Amended Poor Law Act, apparently connected to the new system of classification (Second Annual Report of the Poor Law Commissioners 1836: 5). Additionally, Bentham claimed that a uniform system of workhouses throughout a country increased economic benefits because of savings on relief due to the test of less eligibility, division of labor, less staff required to supervise the residents, and the transparency of the large institution (Bentham 2001b [1796], 1797: 157-167, 168, $169,171,174,187,190)$. Additionally, Ireland was viewed as prone to insurrection so the uniformity of design undoubtedly served a political purpose in control. The workhouses underlined the reach and authority of the British political arm through the Poor Law Commission. As Foucault said, it was a "new physics of power" (Foucault 1977: 208).

\section{Classification and Spatial Segregation Reflected in the Workhouse Plan}

The policy of the classification of paupers was given physical manifestation through spatial segregation throughout the workhouse. Within the workhouse, classification was the division of inmates into definitive groups for administrative purposes. The Commissioners required, at the very least, that men and women were separated. This basic division was not necessarily administratively beneficial but rather a reflection of Malthus' ideology. Separation of the genders prevented procreation, and the creation of further off-spring who would most probably be reliant on poor relief. Malthus argued that the provision of relief was a "direct constant and systematical encouragement to marriage by removing from each individual that heavy responsibility which he would incur by the laws of nature for bringing human beings into the world which he could not support" (Malthus 1807: 28). In practice, the classification in the plan mirrored distinctions made in contemporary Victorian England between the able-bodied and those unable to work. Men, women, boys, girls, elderly men, elderly women, male "idiots," female "idiots," and the sick were separated by the layout of the workhouse, similar to other institutions like asylums. Where possible, these people were obliged to work within the workhouse for their relief. Nicholls wanted to utilize work in the workhouse as a means of discipline and deterrence. He was an ardent Malthus follower and strong believer in the Workhouse Test of destitution (dating back from 1822). Every inmate of the workhouse had to work, not to be productive, but because of the Workhouse Test. It was a kind of "secret punishment" (Foucault 1977: 111). Five different classes of inmates were listed in the 1838 Poor Law Act: Males above the age of 15 years, boys above the age of two years and under that of 15 years, females above the age of 15 years, girls above the age of two years and under that of 15 years, children under two years of age. Ideally, inmates were to be further divided within the categories of age, illness, and mental disposition. Wilkinson's standard workhouse plan paralleled Bentham's idea of the "pauper-land," that is Bentham's Utopian visualization of Panopticon Hill Villages where refuge would be provided for all classes of the poor through centers for industrial training, farming, employment opportunities and even 
music schools (Mack 1969: 192). The work given to the inmates was also classified and segregated. It would almost seem that Nicholls loathed the able-bodied inmates because he directed that their work "should be of such a nature as to be irksome, and to awaken or increase a dislike to remain in the workhouse" (Fifth Annual Poor Law Report 1839: 28). For this type of work, he recommended the corn-mill. However, he could not apply the same test to the children. Instead, they were to be trained to be "useful members of the community", in that the boys would learn manual labour skills and "acquire habits of industry" by working on the small plot of land available in the workhouse (one to two acres recommended size) and the girls would be trained in domestic skills (Fifth Annual Poor Law Report 1839: 32).

\section{Moral Geometry}

The arrangement of the inmates' quarters is significant, reflecting the ideas of a moral geometry. (see Fig. 2). Wilkinson's standard plan clearly portrays a moral hierarchy along a scale ranging from supreme morality to base morality. The building associated with the Guardians, located at the top of this scale, is removed from the inmates' quarters and in essence has contact with the town and those living outside the workhouse. The workhouse children, who are morally closest to the master, have their quarters located around his. The master's quarters are centrally placed, keeping order and symbolically watching over all. In the extreme wings of the workhouse are the adult inmates' wards. Able-bodied adults were considered responsible for their own circumstances and therefore morally baser than the workhouse children. The so-called idiots were removed from the main block towards the back of the workhouse, possibly as the source of a greater moral threat as they were considered unable to judge right from wrong.

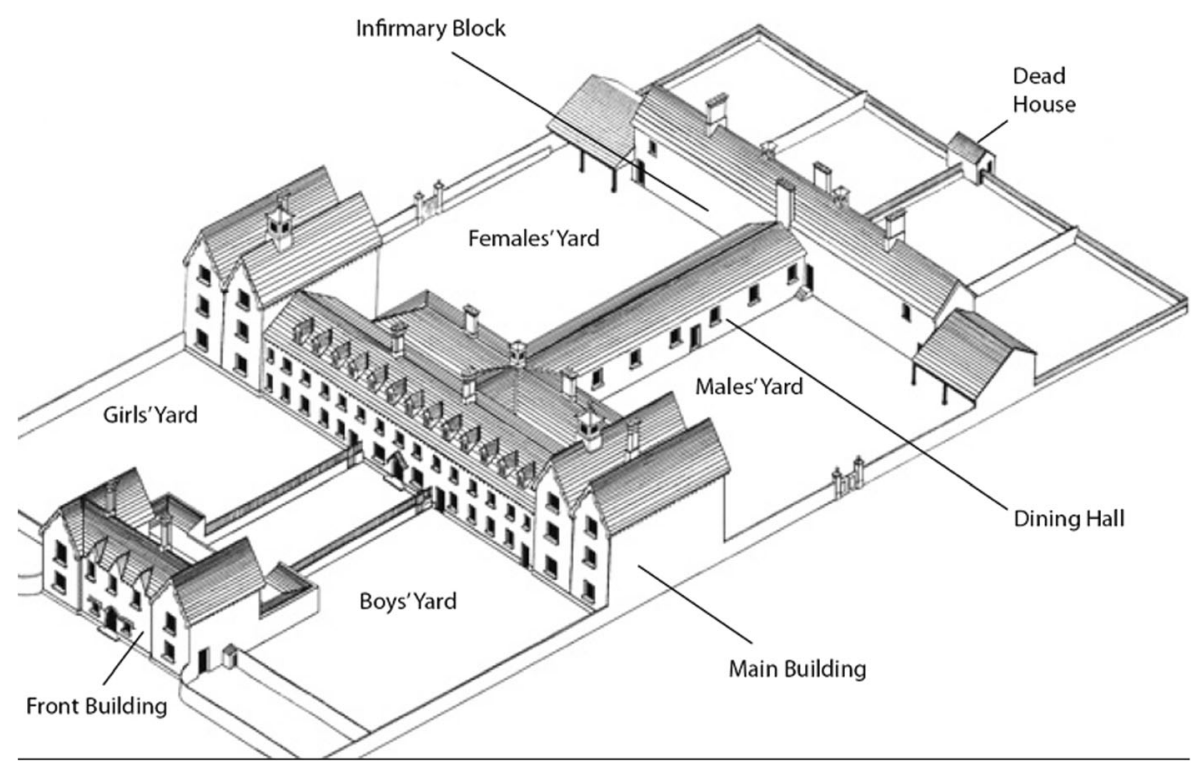

Fig. 2 Wilkinson's plan for 800 inmates (redrawn from Fifth Annual Poor Law Report 1839) 
An important aim of the new Poor Law, inspired by Malthus, was to inspire selfdiscipline - the development of an awareness of prudence among the pauper population. Inmates were not considered criminals, but rather according to Nicholls, the workhouse was the "first step, towards effecting an improvement in the character, habits, and social condition of the people and without such improvement, - peace, good order, and security cannot exist in Ireland" (Nicholls 1837: 11-12). Foucault identified that the "distribution of individual space" was for both"functional" and disciplinary purposes (Foucault 1977: 141-144). However, the treatment of workhouse inmates was close to that of prisoners because they were confined to the workhouse and could not leave without permission. One supporter of the Workhouse system, George Cornwall Lewis, agreed that the workhouse was a prison-like system (Lewis 1837: 10). Every workhouse was enclosed by a high wall or fence, some almost eight-feet tall; some workhouses even had a surrounding ditch (Thomas 2012). It is also worth noting that along the axis of the plan is a clear and direct entry into the workhouse with no opposing exit, making it almost prison-like (Figs. 3, 4, 5, and 6; also see Fig. 2). ).

\section{Religion}

As far as the Commissioners were concerned the two greatest points of contention in Ireland were politics and, religion and because of this, the assistant Commissioners were not permitted to demonstrate any bias. The legislation prevented religious ministers from being elected as Guardians. Additionally, every word of the assistant Commissioners would be "narrowly watched and scrutinized" by the public (Fifth Annual Report of the Poor Law Commissioners 1839: 29). Although there had been instances of party bias amongst some Guardians, and contrary to the Commissioners' intentions to prevent any political prejudice shadowing the elections of guardian and among various Unions in the first year of the act, the Commissioners still maintained that with experience and time, the Guardians in Ireland would be on par with those in England (Fifth Annual Report of the Poor Law Commissioners 1839: 33, 37). In the name of reform, the discussion and display of politics was forbidden and religion existed merely at a pragmatic level in the workhouse, in that no church was permitted to be erected on the site of the workhouse grounds. Instead, the dining area was to be partitioned for worship, depriving the inmates of another social freedom (Fifth Annual Report of the Poor Law Commissioners 1839).

\section{Economy}

Economy and efficiency were also at the heart of the new Act and the reformation of the people. Nicholls considered that the workhouse "will in the end be the cheapest mode of providing relief for the destitute" while still recognizing and maintaining the principle of workhouse classification (Fifth Annual Report of the Poor Law Commissioners 1839: 31). The object of the act was to relieve destitution of the "really and unavoidably destitute" in the "most economical manner" and it was hoped that eventually the cost to the rate-payers would decrease (Fifth Annual Report of the Poor Law Commissioners 1839: 32). Nicholls was stringently economical in all respects including the cost of paying Commissioners and their assistant. He wanted a 


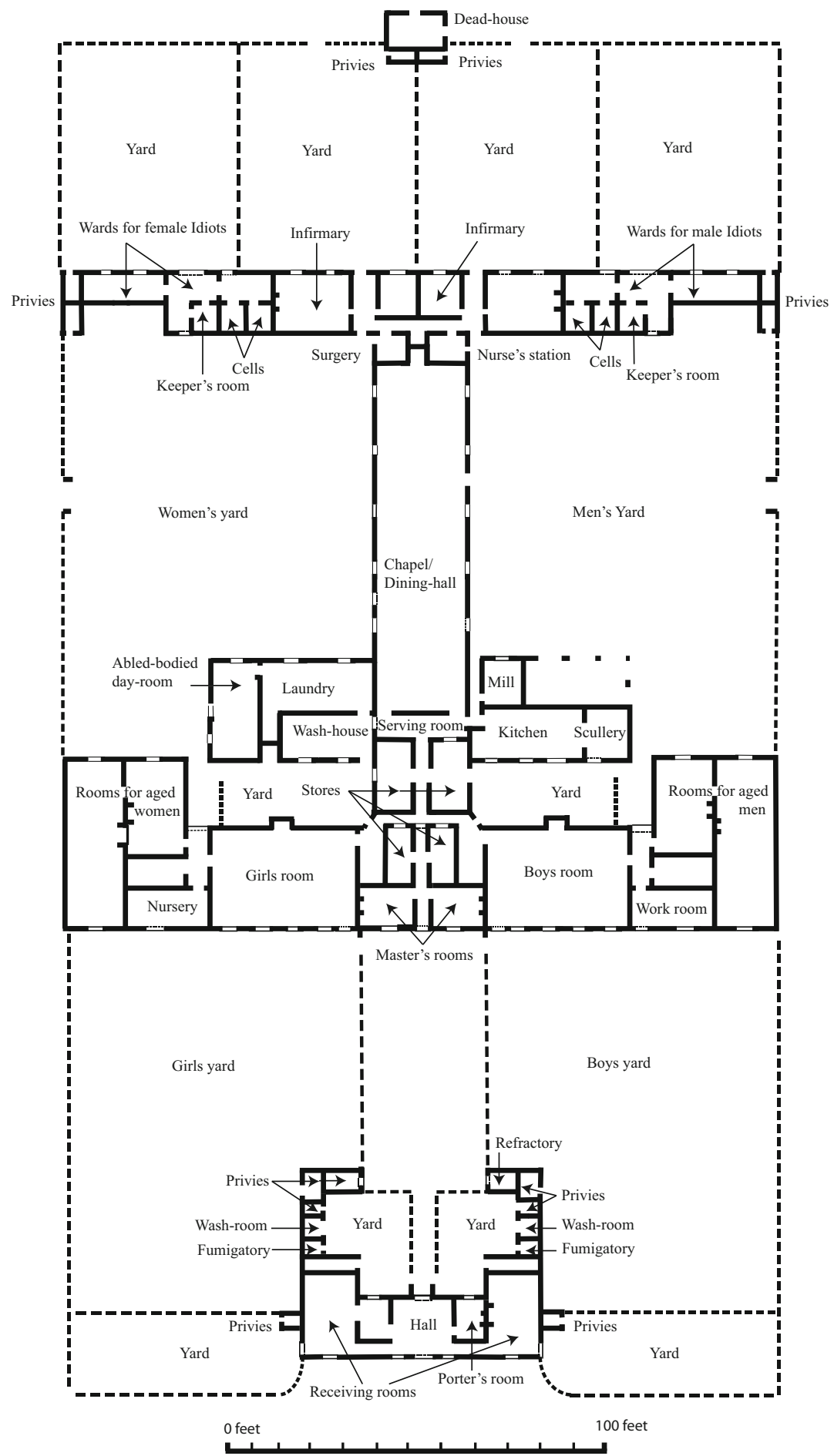

Fig. 3 Wilkinson's plan for 400 to 800 inmates (Fifth Annual Poor Law Report 1839) 
"strict economy in every department rigidly enforced; for, independent of all other considerations, it would be monstrous to permit any unnecessary expenditure in institutions expressly formed for the relief of destitution" (Fifth Annual Report of the Poor Law Commissioners 1839: 32). Wilkinson produced plain elevations and simple designs for decorative features, such as the barge boards, gates, and ventilation towers. The architectural style, like the workhouse inmates' regime, was frugal in nature (Figs. 7 and 8).

The only expense for decoration permitted by the Commissioners was to create the vision of a well-built establishment and ultimately so that "the pauper would feel it was utterly impossible to contend against it" (Head in Jackman 1958: 63).

\section{Education and Training}

Pauperism was considered a hereditary disease. Bentham concluded that education of youth would eradicate this disease, but the Commissioners restricted the education provided mainly to "a careful instruction in useful branches of industry" only to help them become "respectable members of the community" (Seventh Annual Poor Law Report 1841: 47-48). The children were trained according to their rank in society. Boys

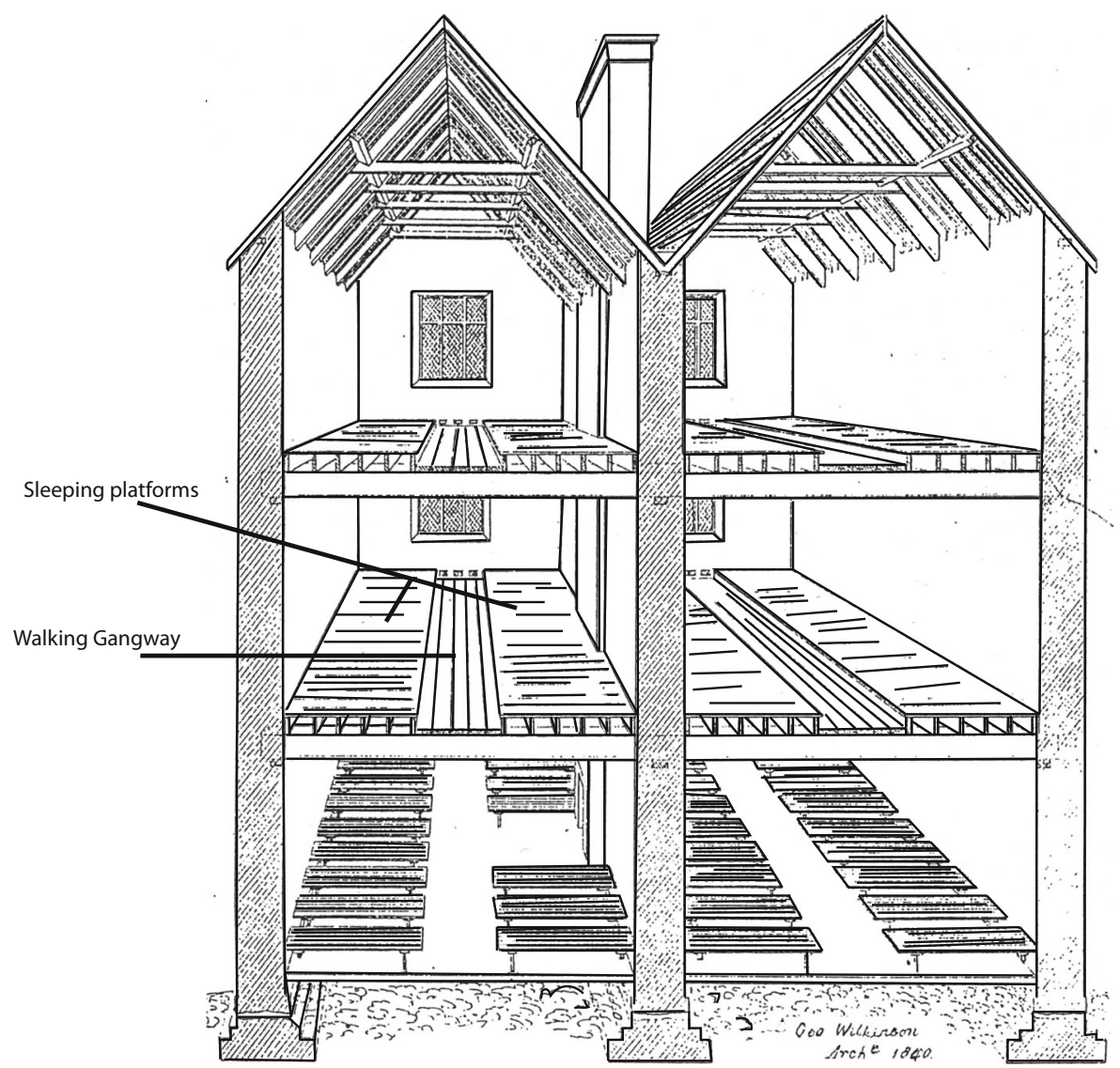

Fig. 4 Wilkinson's sleeping platforms (Sixth Annual Poor Law Report 1840) 


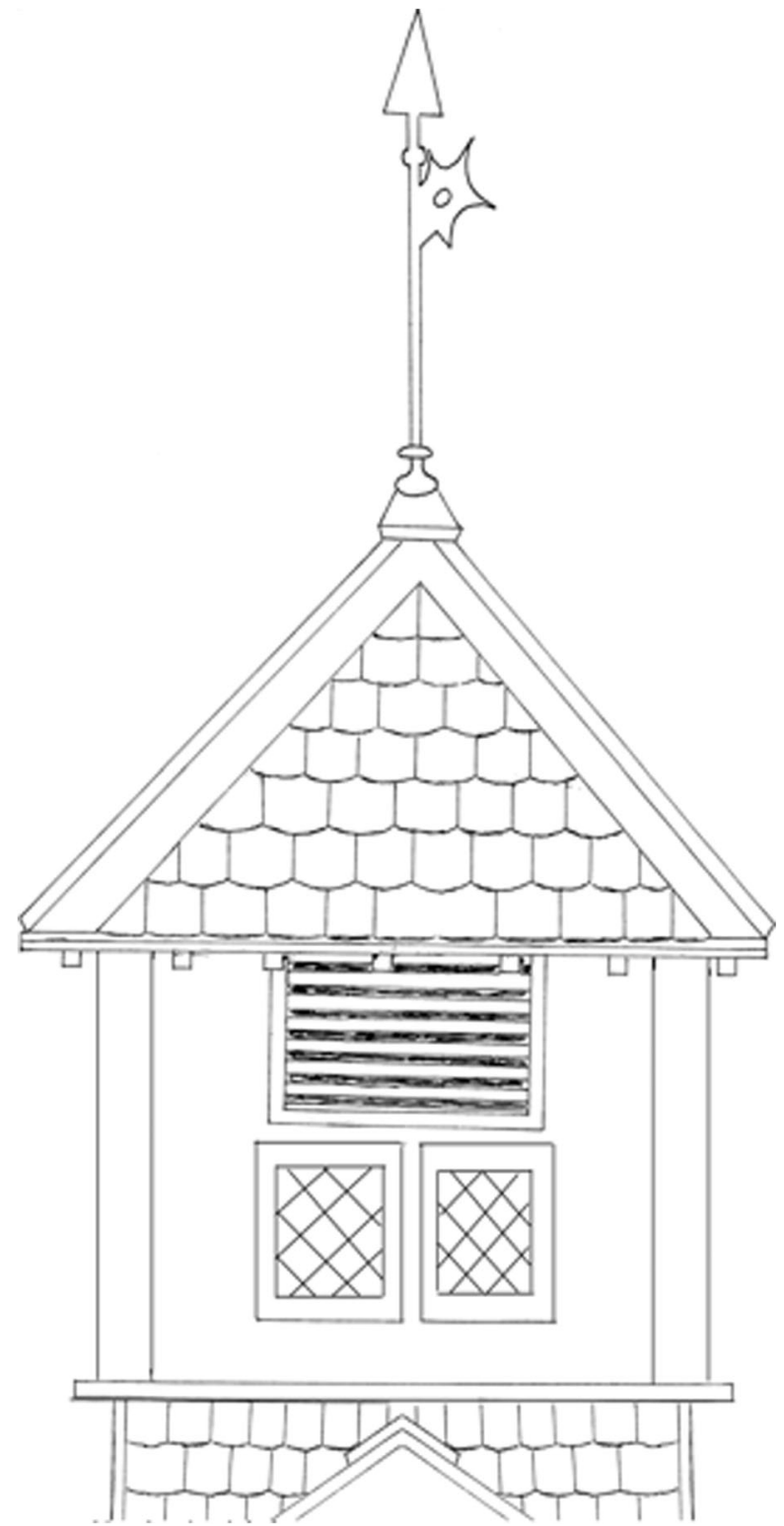

Fig. 5 Drawing of ventilation tower from Wilkinson (Irish Architectural Archives)

were taught how to mend shoes and girls were taught domestic duties, such as sewing and embroidery. Their work areas, on the ground floor, were converted into schoolrooms for three hours during the day. The children were further socially stigmatized by being prevented from attending a local school and studying "literate" subjects (National schools were established from 1831). The standard plan again expressed another ideology of that period, not to banish poverty but to extirpate indigence and maintain the pauper population for labor. 


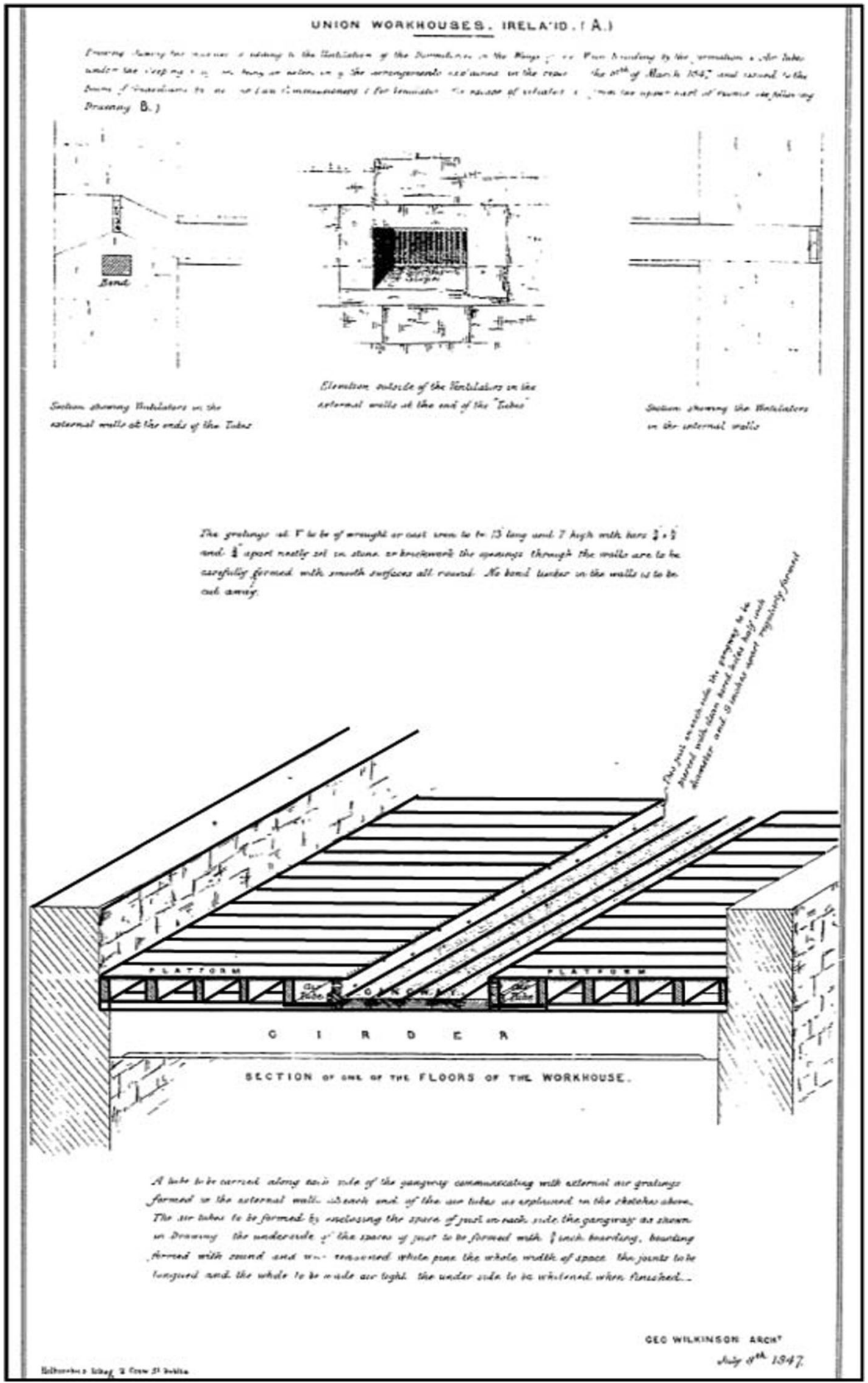

Fig. 6 Drawing of floor with "air-tubes" (A611 vol 4) 


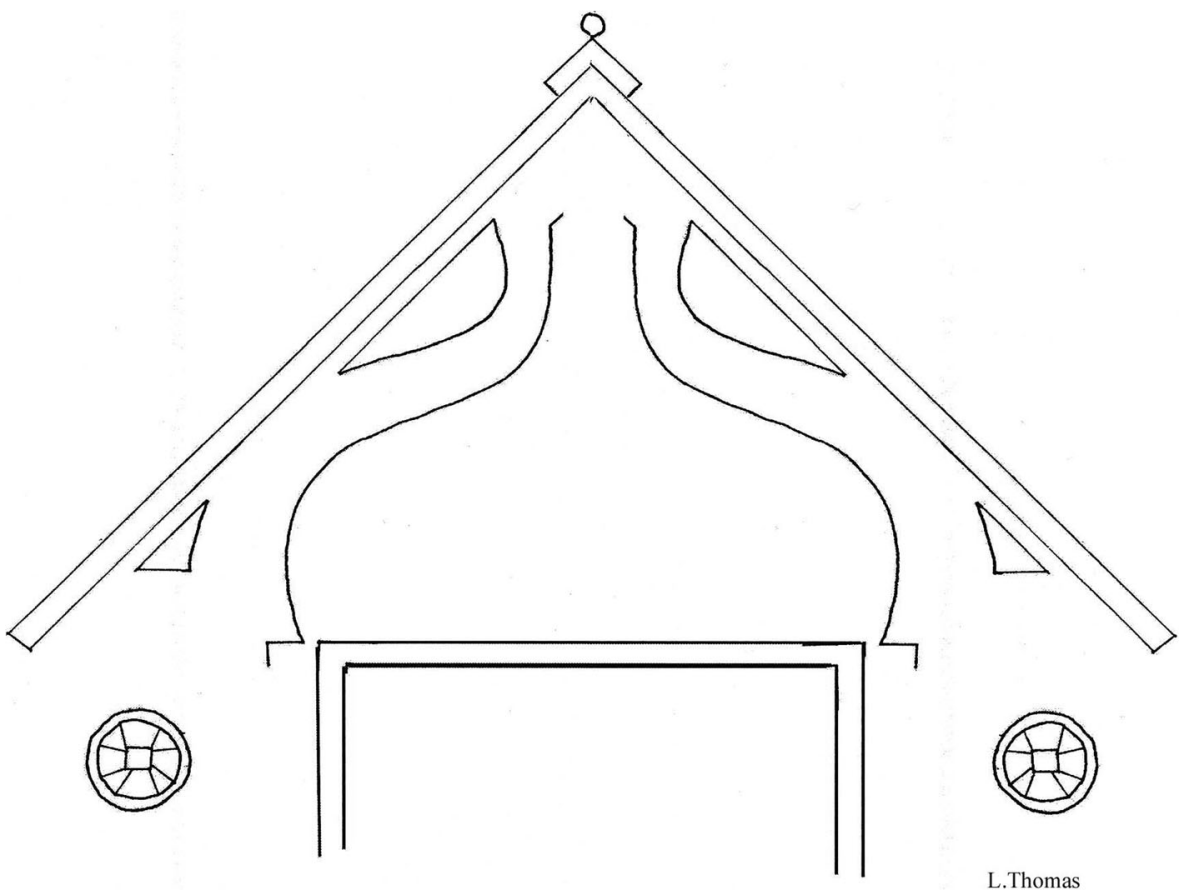

Fig. 7 Wooden bargeboard redrawn from Wilkinson's drawings (IAA)

\section{The Realities of Reform}

The Irish workhouse plan was a physical manifestation of the ideologies that drove the new Poor Law Act (Ireland) and its plan essentially was a physical manifestation of the policies of the new legislation in Ireland: centralization, classification, deterrence, discipline, prudence, and uniformity. Trial and error, with the development of the

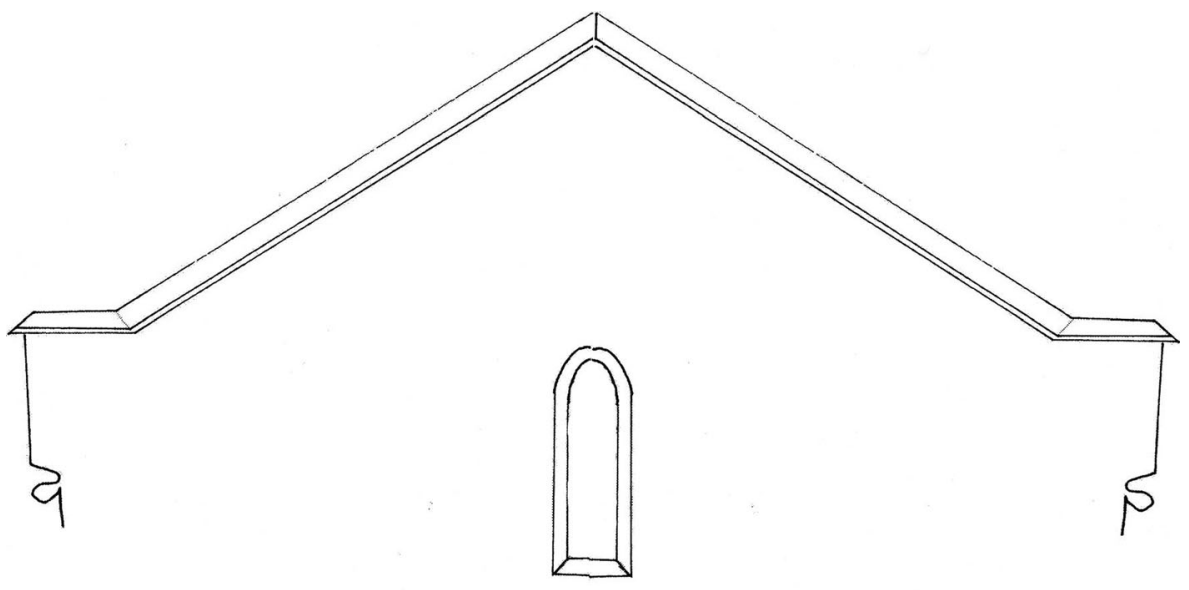

L.Thomas

Fig. 8 Stone bargeboard redrawn from Wilkinson's drawings (IAA) 
workhouse plan in England, resulted in the "perfect" archetypal workhouse in Ireland, where the policies of the new Poor Law were conducted at a practical, administrative, and ideological level. The implementation of such a rigid standard plan was a potent effort to reform the Irish character and ultimately, restore what was considered the natural social order, the then perceived to be correct hierarchal order of society.

\section{Wilkinson's Plan in Practice (1838-46)}

Wilkinson's plan was ideologically sound (in relation to the contemporary values of reform and Improvement) and therefore, in theory, an absolute reflection of the governing ideologies of the Poor Law Act. Practically, however, the plan was an impediment to the enforcement of the ideologies of reform. The implementation of the principles of classification and segregation was the biggest challenge in workhouses across the Ulster province. For example, the Belfast Guardians complained that insufficient space made classification and segregation difficult to enforce. They described it as "nothing less than cruel to confine so many human beings in an apartment so small as that present nursery" (BG/7/a/2: 177). In 1842, there were twice as many men than women in the Belfast workhouse and gender disproportionality existed in various workhouses over the years (BG/7/a/2: 362). Wilkinson had intended that the workhouse buildings would be expanded when extra accommodations were required. Instead, separate buildings were commonly erected on the workhouse sites. Wilkinson's plan was so impracticable in practice that there are numerous instances of the Guardians changing the ascribed room uses. For example, fever patients were placed in the 'idiot' wards, at the back of the workhouse, and in a new nursery until the erection of the fever sheds was completed; in another example, against the Commissioners' advice, even a piggery and straw sheds were converted into dormitories (BG/7/a/4: 174). From the onset, numerous alterations to the use of the buildings and grounds had to be made for the proper implementation of classification and segregation. Across the province of Ulster, actual use of workhouse space was radically different from the planned uses; the strict principle of classification was breeched, in spite of the Commissioners' objections. In many Unions entire classes of inmates were shuffled from one ward to another in order to enforce classification (BG/7/a/2, p. 362). As a consequence, Wilkinson's plan was useless in practice (BG/21/a/2: 3; BG/21/a/1: 177; BG/21/a/1: 217; BG/21/a/2: 2).

In 1843, a provision was made in the Act permitting Guardians, with the Commissioners' sanction, to appropriate a portion of the workhouse to treat fever cases (6 and 7 Vict. C. 92 Poor Relief (Ireland) Act 1843). Within two years, the Commissioners decided that every workhouse, except those in "very peculiar circumstances" should have a separate and distinct fever hospital erected (BG/92/1/1: 95; BG/92/1/1: 94). This directive contravened Wilkinson's idea that the workhouses should be expanded rather than separate buildings erected, and highlighted that his classification scheme was not sufficient (BG/92/1/1: 94). The divergences from Wilkinson's original plan were mainly for practical purposes. Even Wilkinson's assistant architects made recommendations that altered Wilkinson's original plan, such as the construction of separate stores and even "the fitting up of a porter's room." These rooms were usually located towards the front of the workhouse (BG/81/1/1: 112-13; BG/21/a/2: 343; BG/14/a/2: 504). 


\section{The Realities of Reform Among the Workhouse Inmates and Officers: Their Power and Struggle During and After the Great Famine}

In spite of Wilkinson's direct involvement and the pressing authority of the Commissioners, the new buildings, extensions, and alterations effectively distorted the internal and external symmetry of Wilkinson's original workhouse plan. However, the Commissioners continued their earnest efforts to strictly enforce the policies of uniformity, classification, segregation, and the Workhouse Test for the sake of reforming the Irish character. In the context of Irish workhouses, the Workhouse Test embraced the test of less eligibility. Therefore reference to the Workhouse Test is inclusive of the term "test of less eligibility." Because of this strict regime, the struggle between the Commissioners' ideologies and the Guardians' pragmatism came to a climax. Externally, the workhouse was radically altered. Internally, the original plan was altogether lost. This struggle is particularly emphasized in the transient change of room use, as opposed to Wilkinson's intended room use. For practical reasons the ideological plan could not function (Fig. 9).

The Commissioners often objected to the Guardians' solutions to accommodation and classification but seemed ultimately powerless when the Guardians resisted their objections. For example, at Belfast, in spite of the Commissioners' disapproval, cholera inmates were accommodated in the school attic (BG/7/a/16: 51). Whole classes of inmates were moved to maximize capacity and to maintain classification and segregation (BG/7/a/6: 280). On the notice of the Commissioners that men at the Newtownards workhouse could "get over the gate and leave the workhouse," the aged and infirm inmates were moved to the male able-bodied sheds (BG/9/a/11: 454). This class of inmate was less able to climb, and therefore less likely to escape. In addition to the movement of whole classes of inmates, buildings were converted for new room uses (BG/7/a/6: 319). Again, most of these changes were for practical reasons (BG/7/a/7: 439; BG/7/a/6: 181).

From 1846 the Guardians' particularly struggled to meet the crisis of the Great Famine and to implement the policies of the Poor Law: the humane and economic burden of the Famine left them with little time and money for reflection on the architectural style of workhouse extensions and alterations. Wilkinson berated those Guardians, who, in spite of the "distressed state of the country" neglected their buildings (First Annual Report of the Commissioners in Ireland 1847-48: 110-11). Wilkinson scorned their "neglected state." Likewise, the Commissioners regularly remonstrated with the Guardians for failing to upkeep the workhouses. Several of the Guardians had their workhouses painted, in practical dark brown and lead colors after such remonstrations (Fourth Annual Report of the Commissioners in Ireland 1851: 158).

Understandably, the Guardians' attention, especially during the Great Famine, was turned to the management of the workhouse rather than to the architectural style. The workhouse plan - the lay-out of the buildings - was originally designed to control the behavior of the inmates, through classification, segregation, and the organization of the buildings. The Panopticon of the board-room and the master's central location was lost with the evacuation of the Guardians from the board-rooms, from fear of famine-related diseases, and the relocation of the officer's accommodation in several Unions. At Enniskillen, the Guardians were so fearful of contagion that they were known for 


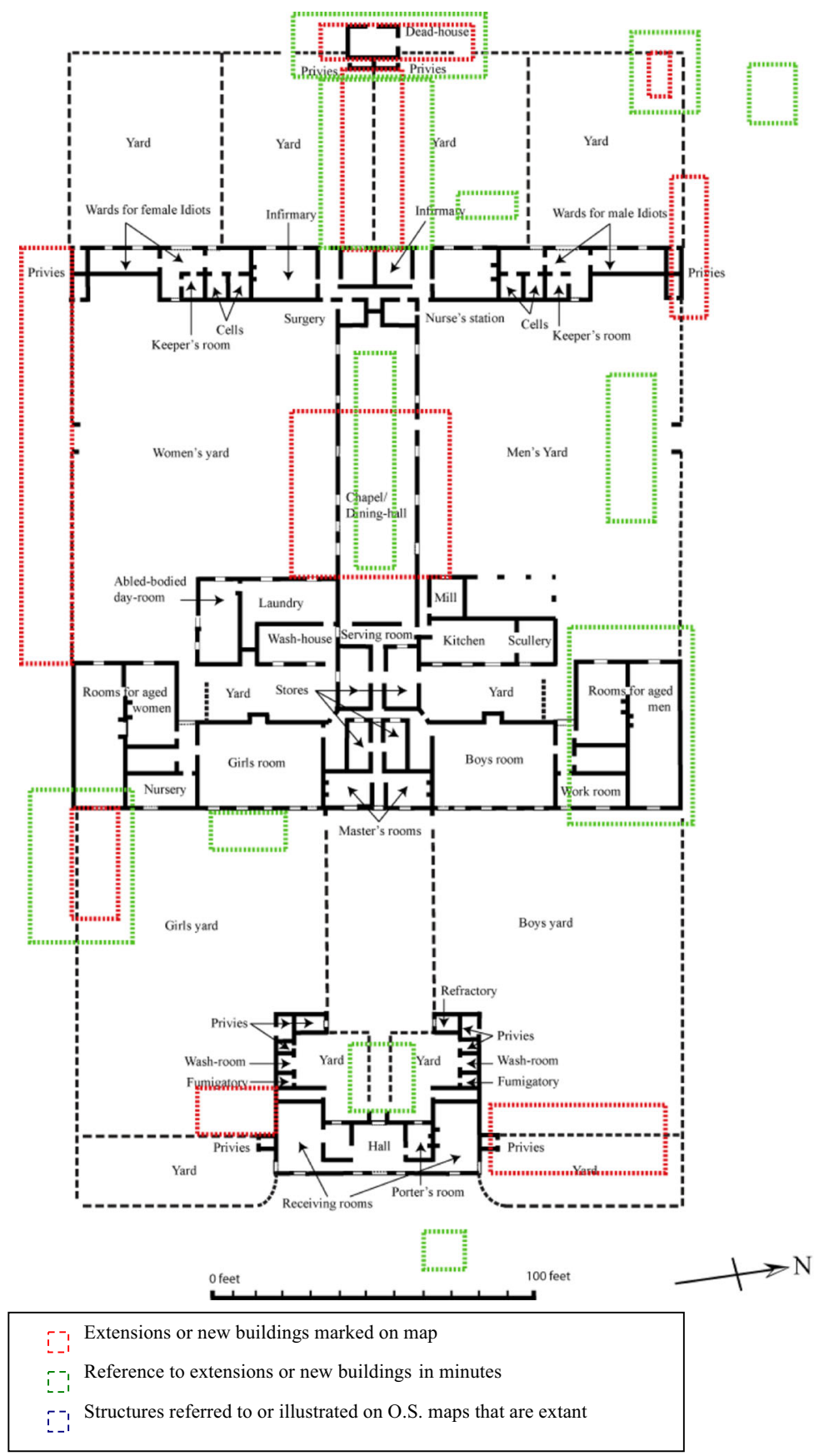

Fig. 9 Change of room use 
"walking backward and forward through the streets" to avoid the masses of beggars (Ó Gráda and McCabe 2009-11: 10). The physical restrictions imposed by the Guardians and Commissioners, such as the raised walls and separation wards, did not stop the breech of classification. From the Great Famine onwards, the workhouse plan no longer controlled the behavior of the inmates, nor officers. Instead, the workhouse structure was, at least somewhat, shaped by the behavior of the inmates. The transient and somewhat unorthodox change of room use reflected the behavior of the workhouse officers and inmates. There was rebellion.

There were riots and attacks outside and within the workhouses by paupers and inmates demanding outdoor relief and a better quality of food (The Essex Standard, and General Advertiser for the Eastern Counties November 19, 1847; The Belfast News-letter 1849). There was an increase in violent and insubordinate behavior recorded in the Guardians' minutes, which was counteracted by harsher, and sometimes illegal, methods of discipline by the Guardians. For example, three Belfast workhouse boys were imprisoned for 14 days on a diet of bread and water for minor theft, and one Donegal inmate, James Cooney aged 18 years, was sentenced to "transportation for seven years" for theft of workhouse property. In this instance, James Cooney was one of approximately 300 individuals who were criminally convicted between 1788 and 1868 and transported from Donegal to Australia (Freeman's Journal and Daily Commercial Advertiser, August 2, 1847a; BG/7/a/11: 257; TR7: 37).

At Strabane, a female inmate was sentenced to six months hard labor for attacking the matron (The Belfast News-letter, 1851). Theft, fighting, and the distribution of contraband articles were common behaviors in several Unions (BG/7/a/5: 239; BG/7/a/11: 257). In fact, during the Great Famine period, over $60 \%$ of young boys and young male adults of the workhouses in Ireland were imprisoned in gaols, where sometimes conditions were better than those in the workhouse, for offences committed in the workhouse (Eight Annual Report of the Commissioners in Ireland 1854-55: 39). Clearly, the workhouse had failed to reform these males. Inmates regularly absconded from the workhouses, destroyed workhouse property, and violently protested against the treatment by the workhouse officers (BG/19A/8; BG/19A/11: 284; BG/9/a/5: 145, BG/ 8/A/4; BG/21A/3: 116-17; BG/21A/4; BG/9/a/4: 54). Many of the workhouse officers across Ulster were also out of control, with some officers assisting the inmates to acquire alcohol, while others indulged in drinking alcohol with the inmates (BG/25A/2: $217-$ 218; BG/7/a/8: 154). One master appealed to his Guardians about the "difficulty he had in restraining some of the officers of the workhouse from going out without leave" (BG/ 21/a/2: 329). At one Union a sophisticated network for the exchange of illicit goods and cash was established between several classes of women across several wards $(\mathrm{BG} / 7 / \mathrm{a} /$ 12: 12). The frequency of pregnancies recorded in the Guardians' minutes indicated that classification was breeched by the officers and the inmates alike. For example, Jane McNeill, a Belfast inmate, was apparently impregnated by Patrick Cann, who was not resident in the workhouse; a shoemaker at the Lisburn workhouse, John Hugh, was "caught taking improper liberties with a female pauper." Of course, Elanor Chapman, the female concerned, "was bound out," that is expelled from the workhouse as punishment because women were generally considered "as temptresses of men" (BG/ 17A/5: 69; First Annual Report of the Commissioners in Ireland 1847-48: 18; SpencerWood 2010: 115-116). 
The abuse of and resistance to the workhouse system by the paupers was evident and recognized by the Commissioners $(\mathrm{BG} / 7 / \mathrm{a} / 9: 40)$. The Commissioners reported that the paupers informed each other about the "best" masters and recommended certain workhouses, which were easiest to enter (BG/16/a/13: 7). Mary Caulfield, aged just 14 years old, is one example. The guardians resolved that she had pretended that she was abandoned by her parents to gain entry into a workhouse. The child was discharged from that workhouse $(\mathrm{BG} / 9 / \mathrm{a} / 5: 105-107)$. On one occasion the master of the Londonderry workhouse complained that the paupers deliberately entered and left the workhouse with the goal "of being immediately after placed on the outdoor relief lists". Outdoor relief was established for a period of time in the wake of the Great Famine (BG/21/a/3: 122). To the consternation of the Commissioners, the Belfast watchman was supplied with a gun and bayonet to prevent the people outside stealing the vegetables from the workhouse grounds (BG/7/a/10: 87).

In the ranks of workhouse officers across Ulster, there were cases of "shameful neglect," accidental killing, theft, and numerous breeches of strict classification, especially with regard to the officers' families residing in the workhouses. Officers' families were forbidden from living within the workhouse (BG/7/a/9: 40; Anglo-Celt 1847; The Standard 1856; Freeman's Journal and Daily Commercial Advertiser 1847b; BG/14/a/6: 348; BG/14/a/7: 49). Often the Commissioners were compelled, mostly by obstinate refusal of the Guardians to follow their instructions, to submit to the Guardians. Inmates were commonly appointed as workhouse officers to the disapproval of the Commissioners. In spite of the Commissioners' strong objections, the Guardians across Ulster permitted inmates to do work not allocated to their classification, such as the girls in the Larne workhouse doing "out door work of the farm" (BG/ 17A/13: 130). There were many disagreements illustrated, through the implementation of the legislation, the struggle of the ideologies of the Commissioners with the pragmatism of the Guardians. The Commissioners' central authority was resented by many of the Ulster unions. The Belfast guardians stated their objection to the central authority of the commissioners and believed that they "sometimes exercise an arbitrary power in matters which would be much better kept in the hands of the guardians" (BG/ 7/a/8: 118). One of the principal disagreements was on the employment of the workhouse inmates and this disagreement illustrated the Guardians' opposition to the Workhouse Test, the underlying principle of the Poor Law. The Guardians universally expressed a desire to profitably employ the men on out-door relief. However, the Commissioners refused to sanction works that were profitable or attractive to the recipients of relief. The Commissioners reinforced that stone-breaking was the only employment that they would sanction (First Annual Report of the Commissioners in Ireland 1848: 11-12; Fifth Annual Report of the Commissioners in Ireland 1852: $12-$ 14). The Belfast Guardians protested against this principle and stated that "that System may obscure the purpose of a useful stimulus to Industry and the consequent prosperity of Ireland (BG/7/a/12: 142). Many Guardians across Ulster believed that the expenses spent on the creation of new officers posts could instead be used for the purchase of a large quantity of land that could be worked profitably by the destitute poor, inside and out of the workhouse. The Guardians at Kilkeel and Newtownards concurred and against the Commissioners' orders, the Kilkeel Guardians hired out a piece of workhouse land for profit (BG/16/a/5: 485; BG/25/a/1: 496; BG/16/a/7: 156). The employment of the inmates extended beyond the prescribed stone-breaking of the 
Commissioners and there are numerous instances where the Guardians breeched the policy of laissez-faire; the Guardians in Belfast sold the workhouse produce, such as manure and potatoes, for profit (BG/7/a/2: 174). In Enniskillen, stones from the quarry were sold and used to finish the stoning of the Fair Green (BG/14/a/1: 280). The Enniskillen guardians reviewed the "industrial manufacture" in their workhouse because they wanted to make a profit "to lessen the expenses of the establishment" and considered the use of the physically and mentally challenged inmates for industry in the workhouse (BG/14/a/12" 344, 374). The Lisburn Guardians made a contract to supply broken stones to the railway and sold their fattened pigs at the local market (BG/19/a/5: 72, 119). The Carrickmacross and Larne Guardians sold the children's produce, embroidery for profit (BG/17/a/15: 20). The Londonderry Guardians investigated how the workhouse produce could be sold profitably and requested information from the Belfast Union on the "particulars" of the manufacture and selling of smelt and picked oakum (BG/21/a/3: $101,119)$.

By 1854 the Commissioners had dismissed 255 workhouse schoolmasters and mistresses across Ireland and this may be part testimony that the officers appeared to have lost control of the workhouses (Eight Annual Report of the Commissioners in Ireland 1854-55: 49). Senior, a commissioner, doubted the Belfast schoolmaster's ability to maintain "proper order and discipline" and had him dismissed (BG/7/a/9, p. 81; BG/7/a/9: 195). The Enniskillen workhouse porter allowed the boys to climb over the walls (BG/14/a/11: 329). Officers were reprimanded for both adhering to and not adhering to the Guardians' instructions. For example, the Glenties workhouse relieving officer was reprimanded by the Guardians for administering out-door relief, while the Lisburn workhouse relieving officer, Richard Dawson, was charged with manslaughter after he enforced a bylaw written by the Guardians that forbade providing transport to the workhouse. Sarah Johnston, "an aged woman" was too weak to walk the $12 \mathrm{mi}(19 \mathrm{~km})$ to the workhouse and "lingered in the house, where shelter had been given her by a poor person, till at the end of five weeks from her first introduction, death put an end to her sufferings" (BG/ 92/1/3: 126; The Belfast News-letter 1851). In an attempt to gain some control, the Belfast Guardians erected bells in certain wards to be sounded in case of unrest (BG/7/a/4: 268).

Despite the Commissioners' earnest efforts, religious contention, (mostly in the form of representatives from the Roman Catholic church and the Protestant church competing for some control over the inmates), among the Guardians, officers, and inmates of workhouses exploded during the Great Famine period. The Commissioners vainly attempted to keep religion and politics out of the workhouse. There was never any permanent church in the workhouse plan. In the original and second-phase workhouses (those 33 workhouses built after 1847) the dining-hall was used as the chapel. At some workhouses, like Belfast, the school-rooms were used for service. The Guardians, in many instances, refused to acknowledge the religious regulations of the Poor Law. There were no Roman Catholic Guardians on the Clones workhouse board, even though two-thirds of the population belonged to that faith. Save for the Roman Catholic chaplain, "all the rest [were] Orange" (Protestant) (Freeman's Journal and Daily Commercial Advertiser Ireland 1846). In fact, the Belfast workhouse Guardians 
refused to recognize Roman Catholic holy days because they believed that Catholicism "encourage[d] idleness and weaken[ed] the industrial habits of the population" (BG/7/a/8: 293).

There were cases of proselytization at several of the Unions, including the Belfast workhouse, where the Guardians were predominantly Protestant (BG/7/ a/7: 386). Apparently, physical force, the dragging of a child's body in one case, alongside threatening words, was used to convert Roman Catholic orphans to "staunch Presbyterians" at the Newry workhouse. It was reported that the Guardians there "decided that it was perfectly fair that physical force should be used to compel them to attend Presbyterian worship" (Freeman's Journal and Daily Commercial Advertiser Ireland 1850). Inmates, including Samuel McCann in Londonderry workhouse and Entwistle, a female inmate at Lisburn workhouse, both suffered epileptic seizures. They both reported that they converted religion on the promise of a cure (BG/21A/3: 41-40; BG/21A/3: 26; BG/19A/ 11: 38-39). The Lisnaskea workhouse Guardians refused the Commissioners' order to provide Roman Catholic books to the inmates (BG/20a/3: 362; BG/20/ a/4: 166). At times, the Commissioners enforced their authority. For example, they dismissed two Guardians, the master, and schoolmaster of the Coleraine workhouse for "marching the boys" on July 12 with "Orange flags." The 12th of July is the traditional date for the celebration of the Protestant King William of Orange who was victorious in the Battle of the Boyne, Ireland in 1688 over the Catholic King James II. (Presently, in Northern Ireland this celebration is still slightly contentious.) However, the Coleraine Guardians refused to communicate with the Commissioners on this matter, giving the impression that they strongly disagreed with the Commissioners' actions (The Morning Chronicle 1853). The Commissioners were frustrated at the Enniskillen workhouse Guardians' laxity towards religion. They allowed inmates to attend religious services that did not match their registered religion (Freeman's Journal and Daily Commercial Advertiser Ireland 1849; BG/14/a/6: 581). This allowance was a problem because it disturbed the desired strict order of the workhouse regime and possibly also caused religious and political agitation amongst the clergy and other influential members of the union.

Many of the alterations made to the workhouses were for the sake of separating children from the other classes. Some minor alterations were distinctly made for the sake of the children's health (BG/25/a/1: 451). However, the more substantial alterations, such as the addition of training rooms and extensions built on the front buildings, mainly for children, were by no coincidence connected to the Guardians' front buildings. By placing the buildings here, the guardians could, of course observe the children, but more importantly the location linked the children closer to the guardians and further away from the other residents. Since 1845 the Clogher Guardians recognized the benefits of moving the children further from the workhouse, and ordered that the girls should be "taken out twice a week for exercise beyond the boundary of the workhouse grounds" (BG/9/a/2: 379-380). According to the Commissioners, children were unlike other residents and were workhouse inmates "through misfortune, wholly unconnected with any default on their own part" and for this reason were permitted "a larger degree of indulgence" (Sixth Annual Report of the Commissioners in Ireland 1853: 6). In particular, Wilkinson's second phase 
workhouse plan at Bawnboy emphasized the special rank ascribed to inmate children: their apartments were at the very front of the workhouse, providing them a vista of hope beyond the workhouse grounds (Thomas 2013).

\section{Conclusion}

By 1855, the Commissioners considered the conditions in the Irish workhouses "normal," that is no longer stretched by or under pressure from the Great Famine, and claimed that even amongst the "peasantry" there were "visible signs of an improved condition of life" (Eight Annual Report of the Commissioners in Ireland 1855: 10-16). The struggle between the Commissioners and the Guardians during the Great Famine period and afterwards was manifested in the behavior of the officers and inmates alike. It was clear that the Ulster Unions struggled, in spite of their claims of reaching "happy results" reflected in the "industrious and orderly habits" of their inmates (BG/7/a/14: 207). The inmates and the "peasantry" also influenced the building lay-out and room use through the bedlam of the Great Famine that infiltrated the workhouse walls. The strict doctrines of the Poor Law were defied. There was abuse of the system on every level, through the breech of classification and segregation, the abuse of the Workhouse Test by the paupers and the Guardians, and the forsaken policy of laissez-faire, when the Guardians continued to sell the workhouse produce at a profit. However, some industrious habits were not profitable to the workhouse, like the flower arranging work of the children at Larne workhouse, and for this reason the training in "flowering" was discontinued (BG/17/a/15: 20). Wilkinson's original plan was changed by external (the Great Famine) and internal forces (residents and officers of the workhouses). Ultimately, the Commissioners' ideal plan failed in its original remit, to classify, order, discipline, and improve the workhouse inmates. In fact Wilkinson's plan was more of an impediment to those Guardians who wished to enforce the Poor Law ideologies, particularly the ideology of reform.

\section{Reflection on Workhouses Today}

In England and Wales the original workhouse system ended in 1930 when the Boards of Guardians were officially disbanded and the workhouses were taken over by local authorities. The workhouses in Ireland, especially those across Ulster (Northern Ireland and the present Republic of Ireland post 1922) shared very different legacies (Table 1).

On the creation of the Irish Free State in 1922, many of the workhouses outside (today's) Northern Ireland (such as those at Dunshaughlin in Meath and Bawnboy in Monaghan) were rumored to have been taken over by both the Black and Tans and the Irish Republican Army during the Irish War of Independence (1919-21) and the Irish Civil War (1922-23). The Black and Tans, who were officially named the Royal Irish Constabulary Reserve Force, were sent to Ireland to assist the Royal Irish Constabulary against the IRA. Larne workhouse was used by the British Army as an internment site under the 1922 Special Powers Act, with up to 279 men (suspected IRA members) interned therein during June 1923 (Kleinrichert 2000). In fact, the cost, approximately $£ 5000$, for converting this workhouse into an internment prison caused some 


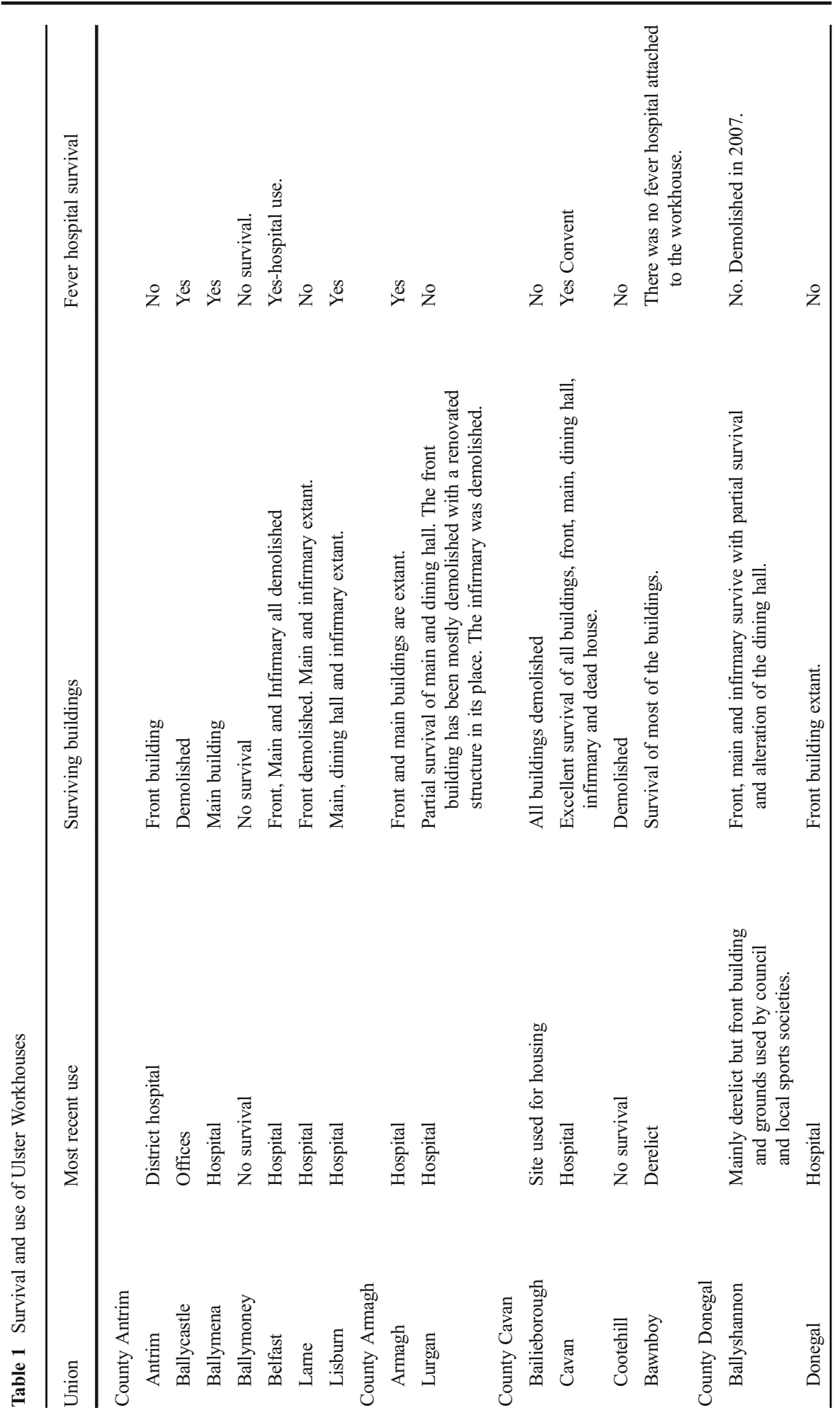




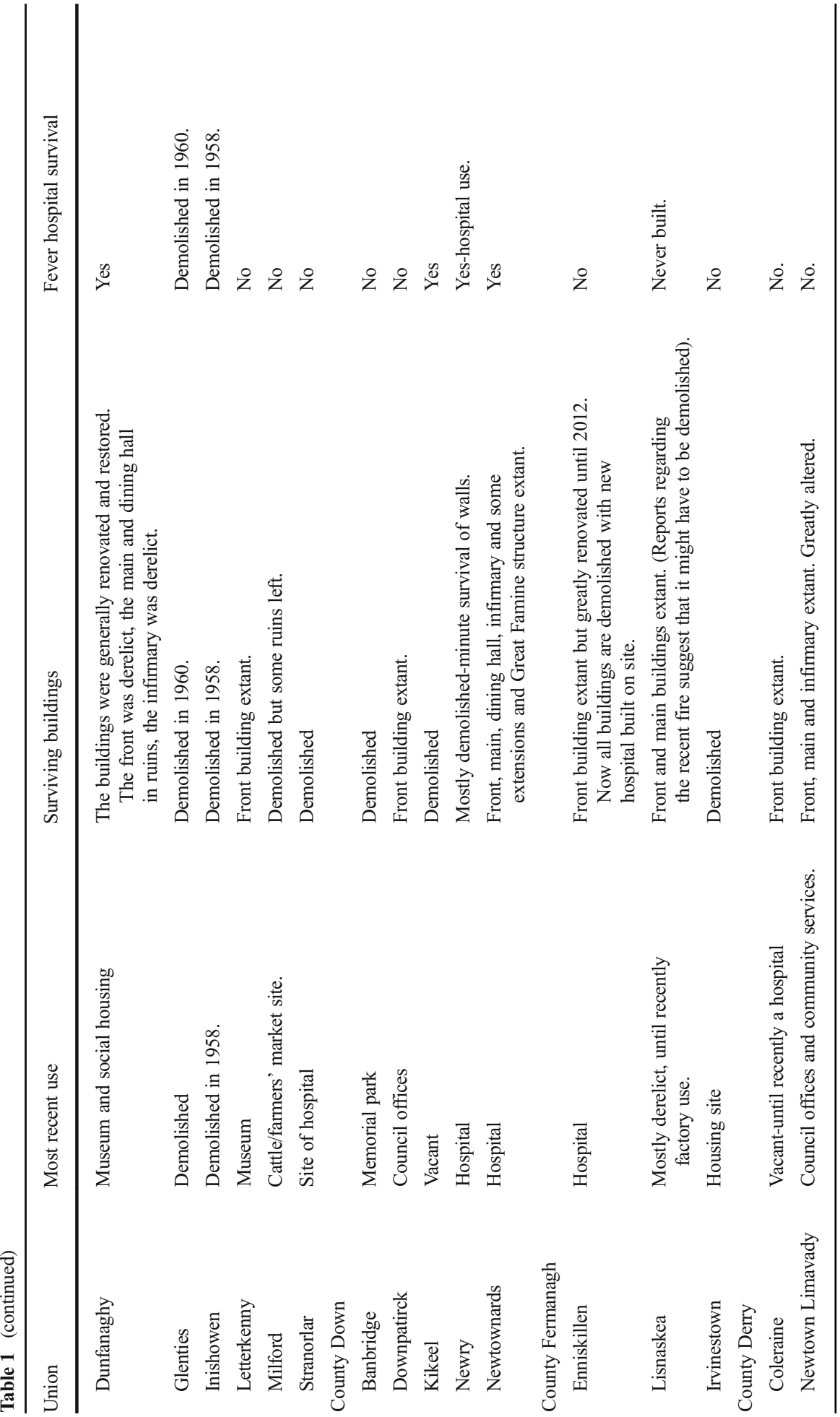




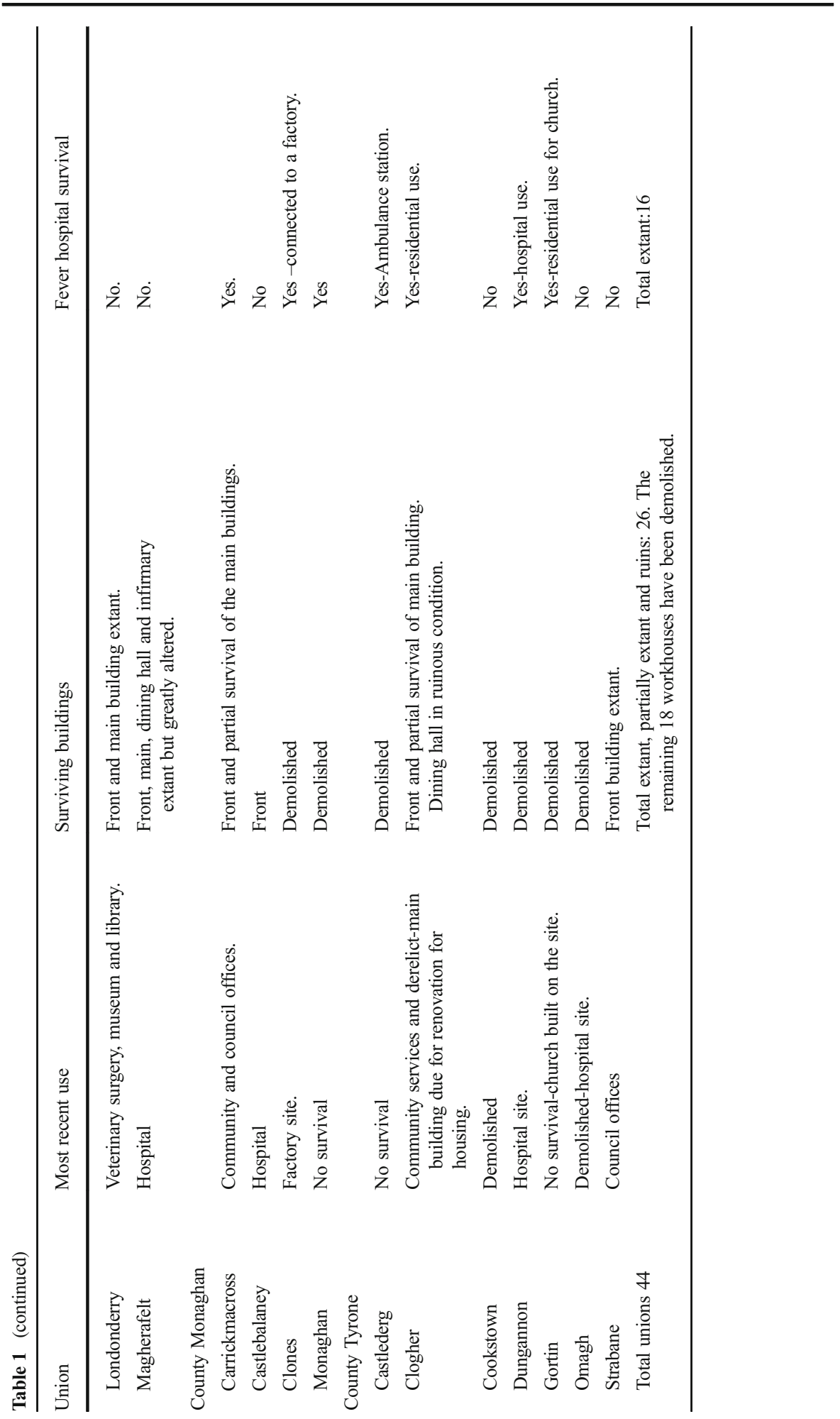


controversy because it was rumoured that the internees were supplied with "a musical band and a platform" (Irish Examiner 1923). The Larne workhouse, now called the Moyle Hospital operates as a rehabilitation and palliative care hospital. The Enniskillen Workhouse was occupied by the Black and Tans, and appears to have been a site of conflict during the Battle of Pettigo (May and June 1922), where two men named Connolly and McEwell, were killed. However, their real names were Bernard McKenna (aged 23) and William Cairney (aged 24) and reported to be members of the IRA. This name change was made by their relatives, "to prevent their bodies being buried in the workhouse grounds by the English authorities"; such was the legacy of fear and loathing of the workhouse in Ireland (Irish Independent 1922a). Used as a general hospital, formerly the Erne Hospital, all buildings related to the workhouse have been demolished recently, to build a new hospital on the former workhouse site, the South West Acute Hospital. The Magherafelt workhouse, was occupied by the Black and Tans during 1922 (Southern Star 1922). Most of the buildings of this former workhouse, now the Mid Ulster Hospital, are extant and renovated for the provision of a range of sub-acute hospital services.

Many workhouses in the present Republic of Ireland were burnt down during the War to prevent the Black and Tans using them as barracks and probably in protest against British rule. The same fate almost happened to at least one in Northern Ireland. The Strabane workhouse is one example when, in February 1922, the IRA made "an ineffectual attempt - with petrol to burn the workhouse buildings at Strabane, where military were due to arrive (Irish Independent 1922b). The Strabane workhouse, now the Strabane District Council offices, offers a wide range of services to the community and district and guided tours are available around the extant front building of which a significant part has been restored and preserved.

The IRA also attempted to occupy some of these buildings during the two wars. It was reported that in 1921 the Ballyshannon Workhouse was occupied by the IRA and provided "an armed sentry at the gate" (Irish Examiner 1921). More recently, this workhouse was used as Council offices (until February 2015) and a care home for elderly people. Much of the main building is derelict.

Another IRA occupied workhouse was Bailieborough. At a special meeting on hearing of the occupation, the Guardians declared "That we have heard with the greatest pleasure that the Workhouse has been taken over by the IRA, and it is our wish that they use it as long as they require it for Brigade quarters" (Meath Chronicle 1921). Afterwards, these buildings were used as a Technical School, a manufacturing site and eventually all buildings were demolished. A nursing home for elderly people now occupies the site (www.workhouses.org.uk).

The Belfast workhouse expanded its buildings dramatically throughout the nineteenth and twentieth centuries, with new buildings including schools, a fever hospital and a maternity block and essentially, initially with the reluctance of the Guardians, grew into a hospital, rather than a workhouse for the poor (Craig 197374: www.ums.ac.uk/inst/hbch_dc.pdf). During the First and Second World Wars the Belfast workhouse served as a hospital for soldiers. Belfast was heavily blitzed in April 1941 (World War Two) resulting in over 900 deaths and 2000 causalities. Although this workhouse grew into a major hospital, it still retained an association to poverty exhibited by major demonstrations in the 1920 s. On one occasion it was reported that "The unemployed of Belfast held a monster demonstration in the city 
today-and-presented themselves at the gates of the workhouse and demanded the admission of a deputation of twelve of their number for the purpose of placing their grievances before the Board of Guardians." It was later reported that the Guardians would not meet with the demonstrators, 5000 in number, "but merely contented themselves by looking through the windows at the seething mass of people" (Irish Examiner 1924).

On the March 28, 1923 the workhouse system was abolished in the new Irish Free State, the present Republic of Ireland (O'Day and Fleming 2014, p. 75). Afterwards, many of these workhouses were used as places of care for the elderly and infirm while some were taken over by Roman Catholic nuns and converted into institutions of education. In Northern Ireland the Poor Law remained in effect through 1948, when it was replaced by the formation of the Welfare State. Similar to the workhouses in the Republic of Ireland, these workhouse buildings continued to house institutions with the purpose of aiding health and wellbeing; many became District hospitals. Although some of the original workhouse buildings have been demolished, new hospitals and care-homes have been built on the original workhouse sites. From personal interviews, life within the institutions, be it orphanage, care home or hospital, after 1948 was no great comfort and the driving principle was still one of strict enforced reform, with a hierarchy of authority emphasized. Over time, many former workhouse buildings were used by the community for all sorts of activities, including dances, lessons, and mother and toddler group meetings. Many of the workhouses, including those in Portumna, County Galway, Carrickmacross, County Monaghan, Londonderry, County Derry and Dunfanaghy, County Donegal have been converted to museums. Limavady workhouse, recognized as one of the best preserved buildings of its type, became the Limavady Cottage Hospital in 1932 until 1998. Owned now by the Limavady Community Development Initiative (LCDI), it houses an interpretative center and guided tours and access to one of the dormitories, the dining area and the graveyard are available. The LCDI is a charity that was founded in 1987 by a group of local people concerned at the high levels of unemployment in the area and now their services extend to providing respite care, child care, social groups for infants to elderly, environmental projects, and transport to the community (www.lcdi.co.uk). Many of these former workhouses, have been the focus of community engagement for young and old, unemployed and skilled to get involved in the conservation and maintenance of these workhouses. In effect, these workhouses continue as sites of community and individual reform, albeit under less harsh circumstances, as people gain new work skills, socialize, and attend self-help groups. Local communities have formed strong emotional connections with these extant workhouses that serve the community. Ironically, in their failure as workhouses, Wilkinson's buildings have become functional sites of reform.

Acknowledgments I am extremely grateful to all those people who have allowed me access to the workhouse buildings and also those who have told me their personal stories about their connection to the workhouses. I am also very grateful to the editors for their advice on earlier drafts of this paper.

Open Access This article is distributed under the terms of the Creative Commons Attribution 4.0 International License (http://creativecommons.org/licenses/by/4.0/), which permits unrestricted use, distribution, and reproduction in any medium, provided you give appropriate credit to the original author(s) and the source, provide a link to the Creative Commons license, and indicate if changes were made. 


\section{References}

Anglo-Celt. (1847). Carrickmacross Union, April 30.

Baugher, S. (2001). Visible charity: the archaeology, material culture, and landscape design of New York City's municipal almshouse complex, 1736-97. International Journal of Historical Archaeology 5: 175202.

Baugher, S. (2010). Landscapes of power: middle class and lower class power dynamics in a New York charitable institution. International Journal of Historical Archaeology 14: 475-497.

Beales, H.L. (1953). The historical context of the essay on population in Glass, D.V., (ed.), Introduction to Malthus. Watts, London, pp. 1-24.

Bernard, T. (1805). Introductory letter to the fifth volume, addressed to William Wilberforce, Esq. M.P. The Twenty-Fifth Report of the Society for Bettering the Condition and Increasing the Comforts of the Poor. Bulmer, London, pp. 1-60.

Bentham, J. (2001a [1796]). Essay One. Definitions and Distinctions. Principles of Penal Law in Quinn, M. (ed.). Writings On The Poor Laws. Oxford.

Bentham, J. (2001b [1796]). Essay Two. Fundamental Positions in Regard to the Making Provision for The Indigent Poor in Quinn, M. (ed.). Writings On The Poor Laws. University Press, Oxford.

Bentham, J. (2001c [1797]). Pauper Systems Compared, or a Comparative View of the Several Systems Establishable as well as Established in Relation to the Poor in Quinn, M. (ed.). Writings On The Poor Laws. Oxford.

BG92/1/1. (1841-48). Donegal Board of Guardian Minutes. Donegal Archives, Lifford.BG29/1/3. (1848-49). Donegal Board of Guardian Minutes. Donegal Archives, Lifford.Casella, E. C. (2000). "Doing trade": a sexual economy of nineteenth-century female convict Australian prisons. World Archaeology 32: 209221.Casella, E. C. (2001). To watch or restrain: female convict prisons in 19th-century Tasmania. International Journal of Historical Archaeology 5: 45-72.

Craig, D.H. (1973-74). www.ums.ac.uk/inst/hbch dc.pdf

Crossman, V. (2003). The New Ross Workhouse Riot of 1887: nationalism, Class and The Irish Poor Laws. Past and Present 179: 135-158.

Crawford, M. (2004). Fermanagh: Food, Famine and Fever in., eds., Eileen M, Murphy, William J. Roulston and William Nolan, Fermanagh History and Society Interdisciplinary Essays on the History of an Irish County, Geography Publications, Dublin.

Crowley, J., Smyth, W. J., and Murphy, M. (2012). Atlas of the Great Irish Famine, Cork University Press, Cork.

Crowther, M. A. (1981). The Workhouse System 1834-1929: The History of an English Social Institution, Batsford Academic and Educational, London.

Daunton, M. J. (1995). Progress And Poverty An Economic And Social History Of Britain 1700-1850, Oxford University Press, Oxford.

De Cunzo, L. A. (1995). Reform, respite, ritual: an archaeology of institutions; the Magdalen Society of Philadelphia, 1800-1850. Historical Archaeology 29(3): 1-168.

De Cunzo, L. A. (2001). On reforming the "fallen" and beyond: transforming continuity at the Magdalen Society of Philadelphia, 1845-1916. Historical Archaeology 5(1): 19-43.

Costello, J. A. (Dec 1913). The leading principles of the Brehon Laws. Studies: An Irish Quarterly Review 2(8): 415-440.

Digby, A. (1986). Malthus and reform of the English Poor Law. In Turner, M. (ed.), Malthus and His Time, St Martin's Press, New York, pp. 41-55.

Fitts, R. (2001). The rhetoric of reform: the Five Points missions and the cult of domesticity. Historical Archaeology 35(3):115-132.

Foucault, M. (1977). Discipline and Punish: The Birth of the Prison, Penguin, Middlesex.

Fraser, D. (2003). Evolution of the British Welfare State, Macmillan, England.

Freeman's Journal and Daily Commercial Advertiser (1846). Conciliation Hall. December 1.

Freeman's Journal and Daily Commercial Advertiser (1847a). Londonderry Borough. August 2.

Freeman's Journal and Daily Commercial Advertiser (1847b). North Dublin Union. October 7.

Freeman's Journal and Daily Commercial Advertiser (1849). Cootehill Union. August 27.

Freeman's Journal and Daily Commercial Advertiser (1850). Physical Force Religion-the Newry "ExGrands" Again. May 18.

General Advertiser for the Eastern Counties (1847). Ireland. November 19.

Gould, M. (2003). George Wilkinson and the Irish Workhouse, M. Phil. dissertation, Queen's University, Belfast. Gray, P. (2009). The Making of the Irish Poor Law, 1815-43, Manchester University Press, Manchester. 
Irish Examiner. (1921). The Truce-Ballyshannon Workhouse Case. November 8.

Irish Examiner. (1924). Belfast's Unemployed-Striking Demonstration Yesterday. January 30.

Irish Independent. (1922a). Situation in Clones. February 17.

Irish Independent. (1922b). Killed at Pettigo. June 8.

Jackman, S. (1958). Galloping Head: The Life of the Right Honorable Sir Francis Bond Head 1793-1875, Phoenix House, London.

Kay, J. P. (1839). Fifth Annual Report of the Poor Law Commissioners; with appendices, The House of Commons, London.

Kleinrichert, D. (2000). Republican Internment and the Prison Ship "Argenta," 1922, Irish Academic Press, Dublin.

Lewis, G.C. (1836, 1837). Remarks on the Third Report of the Irish Poor Inquiry Commissioners; Drawn up by the Desire of the Chancellor of the Exchequer, for the Purposes of Being Submitted to His Majesty's Government; with an Appendix and Supplementary Remarks, London.

Lucas, G. (1999). The archaeology of the workhouse: the changing uses of the workhouse buildings at St. Mary's, Southhampton, Tarlow S. and West S. (eds.), The Familiar Past? Archaeologies of Later Historical Britain, Routledge, London, pp. 125-139.

Mack, M. P. (ed.) (1969). A Bentham Reader, Pegasus, New York.

Malthus, T. R. (1807). A Letter to Samuel Whitbread, Esq, M.P. on His Proposed Bill for the Amendment of the Poor Laws, by TR Malthus, A.M., Late Fellow of Jesus College, Cambridge; and Author of the Essay on the Principle of Population, Wood and Innes, London.

McKee, L. (1992). The ideals and realities behind the designs and use of nineteenth century Virginia slave cabins, In, Yentsch, A. E. and Beaudry, M. C. (eds.), The Art and Mystery of Historical Archaeology: Essays in Honor of James Deetz. CRC Press, Boca Raton, pp. 195-214.

Meath Chronicle. (1921), IRA Welcomed-Bailieboro' Guardians’ Reolution. November 19.

Morrison, K. (1999). The Workhouse: A Study of Poor Law Buildings in England, Royal Commission on Historical Monuments, Swindon.

Nicholls, G. (1837). Report of George Nicholls Esq., to His Majesty's Principal Secretary of State for the Home Department on the Poor laws, Ireland. Oxford and Cambridge University Club, London.

O’Dwyer, F. (1997). Irish Hospital Architecture: A Pictorial History, Dublin Department of Health and Children, Dublin.

Ó Gráda, C., and McCabe, D. (2009-11). 'Better off thrown behind a ditch: Enniskillen workhouse during the Irish Famine'. http://www.ucd.ie/t4cms/wp09.26.pdf. School of Economics, University College Dublin.

O’Day, A., and Fleming, N. C. (2014). Longman Handbook of Modern Irish History since 1800, Routledge, London.

O'Mahony, C. (2008). Emigration from the Workhouses of County Clare 1848-1859, In, Lynch, M., Nugent, P., and Nolan, W. (eds.), Clare History and Society Interdisciplinary Essays on the History of an Irish County. Geography Publications, Dublin, pp. 23-26.

Piddock, S. (2001). An irregular and inconvenient set of buildings: the Destitute Asylum of Adelaide, South Austrlia and the English workhouse. International Journal of Historical Archaeology 5: 73-96.

Piddock, S. (2007). A Space of Their Own: The Archaeology of Nineteenth Century Lunatic Asylums in Britain, South Australia, and Tasmania. Springer, New York.

Poor Law Commission. (1835). First Annual Report of the Poor Law Commissioners for England and Wales, The House of Commons, London.

Poor Law Commission. (1836). Second Annual Report of the Poor Law Commissioners for England and Wales; Together with Appendixes A.B.C.D. The House of Commons, London.

Poor Law Commission. (1840). Sixth Annual Report of the Poor Law Commissioners; with appendices, William Clowes, London.

Poor Law Commission. (1841). Seventh Annual Report of the Poor Law Commissioners; with appendices, William Clowes, London.

Poor Law Commission. (1847-48). First Annual Report of the Commissioners for Administering the Laws for Relief of the Poor in Ireland. Alexander Thom, Dublin.

Poor Law Commission. (1851). Fourth Annual Report of the Commissioners for Administering the Laws for Relief of the Poor in Ireland; with Appendices. G. and J. Grierson, Dublin.

Poor Law Commission. (1852-53). Sixth Annual Report of the Commissioners for Administering the Laws for Relief of the Poor in Ireland, with Appendices. Alexander Thom, Dublin.

Poor Law Commission. (1854-55). Eighth Annual Report of the Commissioners for Administering the Laws for Relief of the Poor in Ireland, with Appendices. Alexander Thom, Dublin.

Public Record Office Northern Ireland. BG/7/a/2. Belfast Board Of Guardian Minutes (November 1842August 1843). 
Public Record Office Northern Ireland. BG/7/a/4. Belfast Board Of Guardian Minutes (October 1845-October 1846).

Public Record Office Northern Ireland. BG/7/a/5. Belfast Board Of Guardian Minutes (October 1846-May 1847).

Public Record Office Northern Ireland. BG/7/a/6. Belfast Board Of Guardian Minutes. (May 1847-February 1848).

Public Record Office Northern Ireland. BG/7/a/7. Belfast Board Of Guardian Minutes (February 1848November 1848).

Public Record Office Northern Ireland. BG/7/a/8. Belfast Board Of Guardian Minutes (November 1848September 1849).

Public Record Office Northern Ireland. BG/7/a/9. Belfast Board Of Guardian Minutes (September 1849September 1850).

Public Record Office Northern Ireland. BG/7/a/10. Belfast Board Of Guardian Minutes (September 1850-May 1851).

Public Record Office Northern Ireland. BG/7/a/12. Belfast Board Of Guardian Minutes (June 1852-January 1853).

Public Record Office Northern Ireland. BG/7/a/14. Belfast Board Of Guardian Minutes (July 1853December 1853).

Public Record Office Northern Ireland. BG8/a/1. Castlederg Board Of Guardian Minutes (June 1839-March 1846).

Public Record Office Northern Ireland. BG8/a/4. Castlederg Board Of Guardian Minutes (October 1851June 1855).

Public Record Office Northern Ireland. BG9/a/4. Clogher Board Of Guardian Minutes (January 1849November 1849).

Public Record Office Northern Ireland. BG9/a/5. Clogher Board Of Guardian Minutes (December 1849September 1850).

Public Record Office Northern Ireland. BG9/a/11. Clogher Board Of Guardian Minutes. (February 1854January 1855).

Public Record Office Northern Ireland. BG14/a/2. Enniskillen Board Of Guardian Minutes (August 1846February 1848).

Public Record Office Northern Ireland. BG14/a/6. Enniskillen Board Of Guardian Minutes (April 1850December 1850).

Public Record Office Northern Ireland. BG14/a/7. Enniskillen Board Of Guardian Minutes (December 1850July 1851).

Public Record Office Northern Ireland. BG14/a/10. Enniskillen Board Of Guardian Minutes (September 1852March 1853).

Public Record Office Northern Ireland. BG14/a/11. Enniskillen Board Of Guardian Minutes (April 1853September 1853).

Public Record Office Northern Ireland. BG16/a/13. Kilkeel Board Of Guardian Minutes (January 1846October 1847).

Public Record Office Northern Ireland. BG17/a/5. Larne Board Of Guardian Minutes (September 1849-July 1850).

Public Record Office Northern Ireland. BG17/a/13. Larne Board Of Guardian Minutes (April 1854September 1854).

Public Record Office Northern Ireland. BG17/a/15. Larne Board Of Guardian Minutes (September 1855September 1856).

Public Record Office Northern Ireland. BG19/a/6. Lisburn Board Of Guardian Minutes. (March 1846November 1847).

Public Record Office Northern Ireland. BG19/a/8. Lisburn Board Of Guardian Minutes (February 1848October 1848).

Public Record Office Northern Ireland. BG19/a/11. Lisburn Board Of Guardian Minutes (August 1850-April 1851).

Public Record Office Northern Ireland. BG20/a/4. Lisnaskea Board Of Guardian Minutes (August 1849March 1851).

Public Record Office Northern Ireland. BG21/a/1. Londonderry Board Of Guardian Minutes (February 1839May 1843).

Public Record Office Northern Ireland. BG21/a/2. Londonderry Board Of Guardian Minutes (May 1843-April 1847).

Public Record Office Northern Ireland. BG21/a/3. Londonderry Board Of Guardian Minutes (April 1847March 1848). 
Public Record Office Northern Ireland. BG21/a/4. Londonderry Board Of Guardian Minutes (March 1848December 1848).

Public Record Office Northern Ireland. BG25/a/1. Newtownards Board Of Guardian Minutes (April 1846November 1848).

Public Record Office Northern Ireland. BG25/a/2. Newtownards Board Of Guardian Minutes (November 1848-October 1851).

Purdue, O. (2011). Poverty and Power: the Irish Poor Law in a north Antrim town, 1861-1921. Irish Historical Studies 37: 567-583.

Scannell, J. (2006). St. Columcille's Hospital, Loughlinstown, County Dublin: from Workhouse Infirmary to General Hospital. Dublin Historical Record 59(2): 153-165.

Skuse, A. and Jones-Owens, R. (1983). Government Intervention and Industrial Policy, Heinemann, London. Slack, P. (1999). From Reformation to Improvement: Public Welfare. Clarendon, Oxford, pp. 1994-1995.

Smith, A. (1805). An Inquiry into the Nature and Causes of the Wealth of Nations, Cadell and Davies, London. Southern Star. (1922). Special shot dead. June 17.

Spencer-Wood, S. M. (2010). Lifeways in the northeastern United States from the eighteenth century through the nineteenth century. Historical Archaeology 44(4): 110-135.

Tarlow, S. (2007). The Archaeology of Improvement in Britain, 1750-1850, Cambridge University Press, Cambridge.

The National Archives of Ireland. (2015) Convicts from Donegal to Australia covering the period 1788 to 1868 (TR7, 37).

The Belfast News-Letter. (1849). Outbreak in Clones Workhouse. July 10.

The Belfast News-Letter. (1851). Assize Intelligence. March 14.

The Essex Standard, and General Advertiser for the Eastern Counties. (1847). Ireland. November 19.

The Morning Chronicle. (1853). Ireland. September 5.

The Standard. (1856). Tuesday Evening. August 19.

Trevelyan, G. M. (1973). English Social History, Longmans, London.

Thomas, L. (2012). Ulster workhouses-ideological geometry and conflict, In, Crowley, J., Smyth, W. J. and Murphy, M. (eds.), Atlas of the Great Irish Famine. Cork University Press, Cork, pp. 156-163.

Thomas, L. (2013). The evolving and physical geometry of childhood in Ulster workhouses, 1838-1855. Childhood in the Past, An International Journal 6(1): 22-51.

Whately, R. (1836). Second Report of the Commissioners for inquiring into the condition of the poorer classes in Ireland, W. Clowes, London. 